\title{
Alkali Effect on Alkali-Surfactant-Polymer (ASP) Flooding Enhanced Oil Recovery Performance: Two Large-Scale Field Tests' Evidence
}

\author{
Chen Sun, ${ }^{1}$ Hu Guo $\mathbb{D}^{1,2,3}$ Yiqiang $\mathrm{Li} \mathbb{C}^{1},{ }^{1}$ Guipu Jiang, ${ }^{4}$ and Ruicheng $\mathrm{Ma}^{5}$ \\ ${ }^{1}$ State Key Laboratory of Petroleum Resources and Prospecting, China University of Petroleum-Beijing, Beijing 102249, China \\ ${ }^{2}$ Institute of Computer Physics, Stuttgart University, Stuttgart 70569, Germany \\ ${ }^{3}$ School of Petroleum and Environment Engineering, Yan'an, Shaanxi 716000, China \\ ${ }^{4}$ No. 4 Oil Production Plant, Daqing Oilfield Company Ltd., Daqing 163511, China \\ ${ }^{5}$ Department of Middle East E\&P, Research Institute of Petroleum Exploration and Development (RIPED), Beijing 100083, China
}

Correspondence should be addressed to Hu Guo; truetutors@126.com and Yiqiang Li; liyiqiang@cup.edu.cn

Received 20 December 2019; Revised 22 February 2020; Accepted 28 February 2020; Published 27 May 2020

Academic Editor: Patricia E. Allegretti

Copyright (c) 2020 Chen Sun et al. This is an open access article distributed under the Creative Commons Attribution License, which permits unrestricted use, distribution, and reproduction in any medium, provided the original work is properly cited.

\begin{abstract}
Alkali-surfactant-polymer (ASP) flooding is very promising chemical enhanced oil recovery (EOR) technology which can make an incremental oil recovery factor (IORF) of $30 \%$ original oil in place (OOIP). How to choose alkali in ASP flooding remains a question for a long time. As the world's only and largest ASP flooding application place, Daqing Oilfield has always adhered to the strategy of parallel development of strong alkali ASP flooding (SASP) and weak alkali ASP flooding (WASP), but SASP is in a dominant position, indicated by more investments and more project numbers. This leaves an impression that SASP is better than WASP. However, WASP is drawing more interest than SASP recently. Moreover, as the ASP flooding in Daqing went from field tests to commercial applications since 2014, how to comprehensively consider the benefit and cost of ASP flooding has become a new focus at low oil prices. This paper compares two typical large-scale field tests (B-1-D SASP and B-2-X WASP) completed in Daqing Oilfield and analyzes and discusses the causes of this difference. The injection viscosity and interfacial tension (IFT) for the two field test areas are substantially equivalent under the conditions of Daqing Oilfield, and WASP is better than SASP when reservoir geological conditions are considered. WASP exhibits the same IORF of $30 \%$ as SASP while having a much better economic performance. For the SASP field test, the injected strong alkali $\mathrm{NaOH}$ makes the test behave unlike a typical strong ASP flooding due to the presence of $\mathrm{CO}_{2}$ in the formation fluid, which well explains why IORF is much higher than all the other SASPs but scaling is less severe than others. This paper confirms that under Daqing Oilfield reservoir conditions, it is the alkali difference that caused the performance difference of these two tests, although some minor uncertainties exist. WASP is better than the SASP providing the same conditions. In addition, the detailed information of the two ASP field tests provided can give reference for the implementation of ASP flooding in other oilfields. After all, the study of ASP flooding enhanced oil recovery technology under low oil prices requires great foresight and determination.
\end{abstract}

\section{Introduction}

Surfactants are important surface-active chemicals with a hydrophobic tail and a hydrophilic head $[1,2]$. Two types of surfactants, natural and synthetic $[3,4]$, are both well studied and widely used. Surfactants are used in different branches of science and technology. They are used as catalysts [5-7] in bioremediation of toxic metals $[8,9]$, hydroformylation reaction [10], and enhanced oil recovery (EOR) [11-14]. EOR involves multidisciplinary collaboration of researchers in physics, chemistry, and reservoir engineering. The most important two aspects of EOR are to increase displacement efficiency by reducing oil/water interfacial tension (IFT) to ultralow with addition of surfactant and to increase sweep efficiency by increasing displacing phase viscosity with addition of polymer. The former is major mechanism in 
surfactant flooding, while the latter is the key idea in polymer flooding $[15,16]$. The combination of polymer and surfactant, surfactant-polymer (SP) flooding, can make very high oil recovery factor. In order to improve oil recovery, alkali is added to SP flooding, which becomes alkali-surfactant-polymer (ASP) flooding [17-20]. Alkali-surfactantpolymer (ASP) flooding is an important chemical flooding enhanced recovery technology $[21,22]$ with wide range of applications $[23,24]$. It can be used in sandstone reservoirs $[23,25,26]$, fault block reservoirs [27-29], conglomerate reservoir [30], and carbonate reservoir [31]. It can be used in medium-high permeability reservoirs $[23,25,26]$ and also a low permeability reservoir [32]. It can be used to recover light oil $[33,34]$ and heavy oil [31]. Completed field tests showed that ASP flooding can produce additional 15-33\% [25] original oil in place (OOIP) upon water flooding. ASP flooding in China is very attractive [35]. As of 2014, among the 32 ASP flooding field tests surveyed, 21 were in China [24], and the majority is strong alkali $(\mathrm{NaOH})$ based. It should be noted that some of China's new ASP flooding projects are not included in the literature [24], like one in high reservoir temperature started in 2011 in Henan Oilfield $\left(81^{\circ} \mathrm{C}\right)[36$ ] and the first weak ASP demonstration block started in 2013 in Daqing Oilfield [37]. The incremental oil recovery factor (IORF) of ASP flooding can be as high as $33 \%$ OOIP and the average IORF is $21.8 \%$ [24]. Most of ASP flooding in China is conducted in Daqing Oilfield, which is summarized in our previous publication [38]. ASP flooding has been put into commercial use in 2014 in Daqing [39]. ASP flooding oil production in Daqing is 3.5 million tons, accounting for $9 \%$ total oilfield production, covering 22 blocks and 7273 wells [37]. In 2016, 3 new ASP flooding blocks were put into use and the annual oil production from ASP flooding is more than 4 million tons [39]. ASP flooding oil production and percentage to total oilfield production are given in Figures 1 and 2 [40], respectively. Although both strong ASP flooding (SASP) and weak ASP flooding (WASP) have been developed in Daqing Oilfield and huge amount of money has been invested to this EOR technology, the number of SASP completed in Daqing Oilfield is much more than WASP according to a previous summary [24]. However, the ASP flooding in Daqing is going toward WASP [37]. A study of ASP flooding cost in Daqing Oilfield shows that the ASP flooding is economically feasible in Daqing when the cost of oil is $22-35 \mathrm{USD} / \mathrm{bbl}$ [35]. Since more SASP flooding tests were conducted in Daqing than WASP, it is necessary to think why SASP gives way to WASP. Considering the scale and stage of ASP flooding in Daqing Oilfield, this issue is of great significance. If ultralow acid value oil in Daqing can be well produced by ASP, for many other reservoirs with much high acid value of oil and higher permeability than Daqing, ASP flooding has great potential. Our previous publication $[40,41]$ has investigated ASP flooding; however, due to lack of geology information, it is less convincing to conclude that WASP is better than SASP and less informative for other fields where ASP flooding may be used. In this paper, the technical and economic differences between the SASP and WASP field tests completed in Daqing Oilfield are analyzed and compared. It is confirmed by the field test performance that the WASP is better than SASP. At the same time, it provides more detailed geological, reservoir physical, and formation fluid information, which is convenient for other similar blocks to carry out ASP flooding. After all, it is necessary to have the courage and determination to invest in ASP flooding technique under low oil price. As for typical screening of surfactants and polymers as well as ASP in China, one may refer to other references [42-48].

\section{Comparison of Test Blocks}

The two ASP flooding field tests compared in this paper are both industrial tests in Daqing Oilfield. Compared with the earlier pilot tests, the industrial test scale in Daqing Oilfield is much larger, which includes generally dozens of injection wells (or injectors) and production wells (or producers), while a pilot test mostly contains 4 injection wells and 9 production wells. The screening of ASP flooding involves multiple factors $[23,24,26,47,49]$, especially the geochemical properties of the reservoir [50-55], properties of crude oil [56-59], properties of the formation water and the inject water [60-63], and the interaction between ASP system and the stratum minerals as well as oil-water $[25,51,53,60,61,64-71]$. To make it easier for readers to understand the differences between the two field tests and to make it convenient to provide a reference for the implementation of ASP flooding in other potential reservoirs, we compared the geology and reservoir properties of the two field tests in detail in this paper. And some key indicators of the two test fields are shown in Table 1. Table 1 is collected from various references above. Since the injection and production in the central well area are relatively complete, if not specifically stated, the IORF from ASP flooding in many publications mainly refers to the central well area. However, it is easy to get confused because some researchers just used the higher value without special note.

For convenience, the weak ASP flooding (WASP) refers specifically to the ASP field test using $\mathrm{Na}_{2} \mathrm{CO}_{3}$ as alkali in $\mathrm{B}-2-\mathrm{X}$ block and the strong ASP flooding (SASP) refers to the ASP field test using $\mathrm{NaOH}$ as alkali in $\mathrm{B}-1-\mathrm{D}$ block in this paper unless specially stated. To be simple, in this paper WASP refers to B-2-X and SASP refers to B-1-D.

Table 1 indicates that $\mathrm{B}-1-\mathrm{D}$ and $\mathrm{B}-2-\mathrm{X}$ have most comparable parameters. In this table, the same parameters are in roman while significant parameters are in italics. Underlined values are estimated because no data are available. The same parameters include well pattern and well spacing, as well as well density in central well area. Formation temperature and brine are regarded as engineeringly the same based on its influence to EOR. Three parameters, average permeability, average sandstone thickness, and effective sandstone thickness, are different. Average reservoir permeability of B-1-D is much higher than B-2-X, although they both remain in the medium permeability range which is good to conduct chemical EOR. Average formation thickness of B-1-D is higher than B-2-X too. It is worth to note that average permeability can only partly reflect the reservoir permeable property but is one key parameter to learn about a 


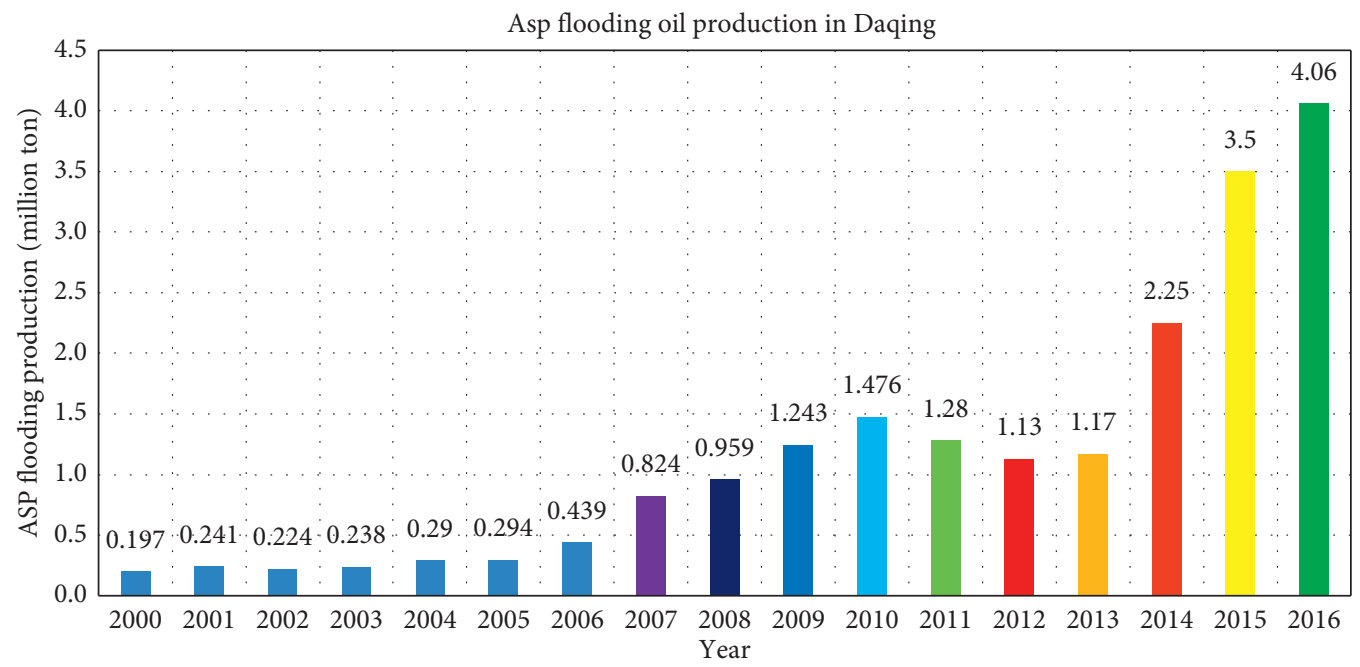

Figure 1: ASP flooding oil production in Daqing Oilfield [40].

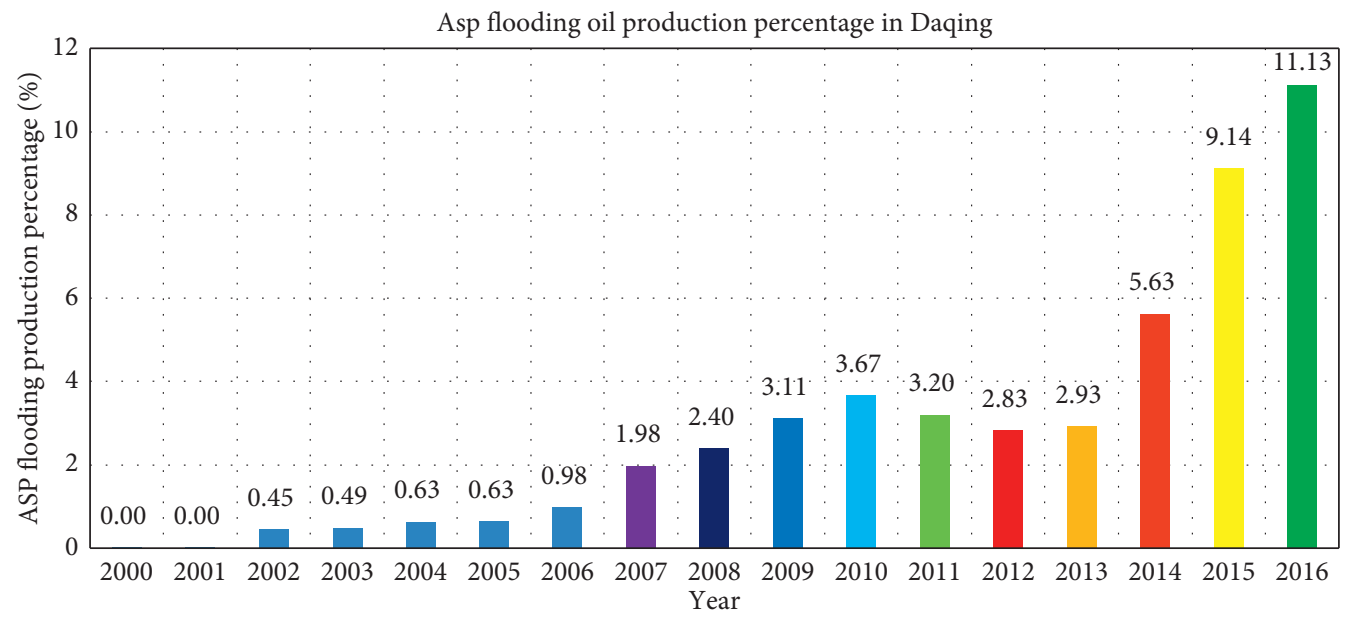

FIGURE 2: ASP flooding production share in Daqing Oilfield [40].

TABLE 1: Comparison of basic reservoir physical properties.

\begin{tabular}{|c|c|c|c|c|}
\hline \multirow{2}{*}{ Parameters } & \multicolumn{2}{|c|}{ Whole test area } & \multicolumn{2}{|c|}{ Central well area } \\
\hline & B-1-D & $\mathrm{B}-2-\mathrm{X}$ & B-1-D & B-2-X \\
\hline Area, $\mathrm{km}^{2}$ & 1.92 & 1.21 & 1.13 & 0.79 \\
\hline Injectors/producers & $49 / 63$ & $35 / 44$ & $49 / 36$ & $35 / 24$ \\
\hline Well density $\left(1 / \mathrm{km}^{2}\right)$ & 58.33 & 65.28 & 75.22 & 74.68 \\
\hline Average sandstone thickness (m) & 10.6 & 8.1 & 11.8 & 8.8 \\
\hline Average effective thickness (m) & 7.7 & 6.6 & 8.4 & 7.1 \\
\hline Average effective permeability(D) & 0.670 & 0.533 & 0.675 & 0.529 \\
\hline OOIP $\left(10^{4}\right.$ ton $)$ & 240.71 & 116.31 & 143.41 & 75.64 \\
\hline Pore volume $\left(10^{4} \mathrm{~m}^{3}\right)$ & 505.11 & 219.21 & 298.44 & 142.66 \\
\hline Well pattern & Five-spot & Five-spot & Five-spot & Five-spot \\
\hline Well spacing $(\mathrm{m})$ & 125 & 125 & 125 & 125 \\
\hline Formation water type & $\mathrm{NaHCO}_{3}$ & $\mathrm{NaHCO}_{3}$ & $\mathrm{NaHCO}_{3}$ & $\mathrm{NaHCO}_{3}$ \\
\hline Formation brine salinity $(\mathrm{mg} / \mathrm{L})$ & 5611 & 6037 & 5611 & 6037 \\
\hline Calcium ion $(\mathrm{mg} / \mathrm{L})$ & 35.97 & $\underline{20}-\underline{40}$ & 35.97 & $\underline{20}-\underline{40}$ \\
\hline Magnesium ion (mg/L) & 9.44 & $\overline{10}-\overline{20}$ & 9.44 & $\underline{10}-\underline{20}$ \\
\hline Target formation & SII1-9 & $S \overline{I I} 10-12$ & SII1-9 & $S \overline{I I} 10-12$ \\
\hline Formation depth $(\mathrm{m})$ & $838-870$ & $\underline{872}-\underline{883}$ & $838-870-$ & $\underline{872}-\underline{883}$ \\
\hline Formation-oil viscosity $(\mathrm{cP})$ & $8.2-9.3$ & $\overline{8.2}-\overline{10.4}$ & $8.2-9.3$ & $\overline{8.2}-\overline{10.4}$ \\
\hline Dead oil viscosity $(\mathrm{cP})$ & 17.55 & 16.6 & 17.55 & 16.6 \\
\hline Formation temperature $\left({ }^{\circ} \mathrm{C}\right)$ & 42.4 & $43-48$ & 42.4 & $43-48$ \\
\hline
\end{tabular}


reservoir. Table 1 shows that these two blocks are very similar and comparable, while B-1-D is better than B-2-X.

2.1. Geological Comparison. The two target reservoirs are all second-class layer (SCL) [72-76]. In lots of literatures about Daqing Oilfield, the second-class layer (SCL) [26] is often involved, but many researchers even in China are not clear about this concept. It is necessary to introduce this concept well to help understand the geological parameters. SCL is a concept proposed during the process of analyzing different layer geological features of each reservoir in Daqing Oilfield. Specific criteria for the classification are shown in Table 2 [72]. It is obvious from Table 2 that the physical properties of the SCL are worse than those of the first-class layer (FCL) and better than those of the third-class layer (TCL) from reservoir engineering perspective. Figure 3 [77] shows the photograph of cores from FCL and SCL. Table 3 [72] shows the comparison of the pore structure of FCL and SCL. This table indicted that SCL pores are smaller and heterogeneous than FCL pores. The classification of three layers is based on both geological and reservoir engineering considerations.

The sedimentary environment of the Saertu-Putaohua (S-P) layer in Daqing Oilfield is river delta, which belongs to clastic reservoirs. The lithology is mainly fine sandstone, fine siltstone, and argillaceous siltstone. Sandstone composition is mainly feldspar (27-55\%) and quartz (29-40\%). The grain size is mainly fine sand, the median grain size is between 0.08 and $0.175 \mathrm{~mm}$, and the sorting coefficient is $2.1-4.8$. The roundness of grit is mostly subcircle to subpoint. Loose cementation is dominated by contact and pore contact cementation. The cement is mainly muddy (muddy content 6-16\%), followed by carbonate (less than 6\%). The main clay mineral composition of the cement is kaolinite, followed by illite, and the secondary rock is weak. The storage space of the reservoir is mainly composed of primary pores and intergranular pores, the reservoir depth is $700-1200 \mathrm{~m}$, the porosity is $22-26 \%$, original oil saturation is $56-76 \%$, and permeability to air is $0.2-1.6 \mu \mathrm{m} 2$.

SASP B-1-D block is located on the top of the Saertu anticline structure in Daqing Oilfield. The structure is gentle, the formation dip is $1^{\circ}-2^{\circ}$, and there are no faults in the area. From the top to bottom, there are three oil-bearing strata, Saltu (S), Putaohua (P), and Gaotaizi (G). The target formation of B-1-D is SII-9. It is river delta sedimentation. The main component of the cement is kaolinite, followed by illite. The clay mineral composition of SASP and WASP is shown in Tables 4 and 5, respectively. These data indicated that the clay content of these two test formation is quite similar, while the clay content of WASP is higher. And the granularity size is smaller too. This is consistent with permeability data shown in Table 1 . Higher clay content may lead to high chemical adsorption in chemical EOR. Nevertheless, there is no criteria of clay content for ASP flooding. WASP B-2-X is located on the west side of the North Sartu anticline structure in Daqing Oilfield. The structure has a relatively gentle stratification angle of $1^{\circ}-3^{\circ}$. Only one fault is developed, and the breakpoint is mudstone, which has no effect on the position of the reservoir. The reservoir conditions of Daqing Oilfield can be found in references $[78,79]$. Clay content of SASP is shown in Table 6. However, clay content data of WASP are not available. High content of kaolinite results in water sensitivity. Daqing Oilfield reservoir is shown in Figure 4. In Figure 4, the largest red part contains most reserves. The well patterns for the two tests are shown in Figure 5.

\section{Sedimentary Characteristics}

A deep understanding of the reservoir is helpful to conduct a field test. The relative location of these two tests in Daqing is shown in Figure 6 [40]. These two blocks are not far away from each other. However, their geology may differ. According to the anatomical results of subdivided sedimentary facies, the SII1-9 layers in the test area are mainly dominated by delta facies deposits. The plane distribution is complex, and the channel sand body width is small. Heterogeneity is obvious. The sand bodies with various deposition characteristics in the longitudinal direction of ASP flooding appear alternately and can be divided into 4 types of deposition, as shown in Table 7 [72]. Table 8 [72] shows the thickness and permeability of each layer in the strong alkali test area.

WASP layer SII is developed with plain delta deposit with main reservoir sand body dominated with low bending distributary plain facies sand body. SII9 to SII13 $+14 \mathrm{~b}$ are divided into six deposition units, and the number of units and deposition characteristics are shown in Table 9 [74]. The target layer SII10-12 sublayer thickness and permeability distribution are shown in Table 10 [54].

It can be seen from these tables that the effective permeability of SASP layers is much higher than that of WASP. But WASP has fewer layers, which are easier for polymer injection. Previous studies indicated that variation coefficient between 0.6 and 0.8 is best for polymer flooding. And these two blocks fall in this range. It is worth to note that these two blocks belong to different operators. Too many layers in B-1-D make it more difficult to select injection ways, separate layer injection, or overall injection. In view of sublayer number of these two blocks, it appears that B-2-X is relatively better than B-1-X.

\section{Fluid Comparison}

Crude oil composition has an important effect on interfacial tension (IFT) [56, 60, 61, 82]. Research shows that the content of active materials of different components in crude oil is different, and their contributions to the formation of ultralow IFT are different [83]. The crude oil is extracted into four components of saturated hydrocarbons, aromatic hydrocarbons, asphaltene, and pectin. The detailed process of separation can be found in the literature [83]. The ability of the crude oil composition to reduce the IFT in presence of surfactant ORS-41 and alkali $\mathrm{NaOH}$ is pectin $>$ asphaltene $>$ aromatic hydrocarbon $>$ saturated hydrocarbon, as shown in Figure 7 [83]. Some scholars believe that asphaltenes in heavy oil have a higher ability to reduce interfacial tension than pectin for heavy oil [60]; this may be 
TABLe 2: Reservoir classification [72].

\begin{tabular}{|c|c|c|c|c|c|c|}
\hline \multirow[b]{2}{*}{$\begin{array}{l}\text { Reservoir } \\
\text { classification }\end{array}$} & \multirow[b]{2}{*}{ Distribution } & \multirow{2}{*}{\multicolumn{2}{|c|}{ Monosandbody }} & \multicolumn{3}{|c|}{ Basic reservoirs characteristics } \\
\hline & & & & $\begin{array}{l}\text { Effective } \\
\text { thickness, } H \\
\text { (m) }\end{array}$ & $\begin{array}{l}\text { Permeability, } K \\
(\mathrm{mD})\end{array}$ & Scale \\
\hline $\begin{array}{l}\text { First-class } \\
\text { layer(FCL) }\end{array}$ & PI group & River sand & $\begin{array}{l}\text { Flood plain facies } \\
\text { channel sand, highly } \\
\text { curved diverting } \\
\text { channel sand }\end{array}$ & $\geq 4 \mathrm{~m}$ & $\geq 500$ & $\begin{array}{l}\text { Formation developed with } \\
\text { large area, with a width } \\
\text { greater than } 1000 \mathrm{~m}\end{array}$ \\
\hline $\begin{array}{l}\text { Second-class } \\
\text { layer (SCL) }\end{array}$ & $\begin{array}{l}\text { S group and PII } \\
\text { group }\end{array}$ & River sand & $\begin{array}{l}\text { Low-bend diversion } \\
\text { channel sand, } \\
\text { underwater dendritic } \\
\text { channel sand }\end{array}$ & $H \geq 1.0 \mathrm{~m}$ & $\geq 100$ & $\begin{array}{l}\text { Formation developed } \\
\text { connected with a width } \\
\text { greater than } 200 \mathrm{~m}\end{array}$ \\
\hline \multicolumn{7}{|c|}{ Nonriver sand $\mathrm{H} \geq 1.0 \mathrm{~m}$ with oil layer assisted } \\
\hline $\begin{array}{l}\text { Third-class } \\
\text { layer (TCL) }\end{array}$ & $\begin{array}{l}\mathrm{S} \text { group, } \mathrm{PII} \\
\text { group, and } \mathrm{Gao} \\
\text { group }\end{array}$ & $\begin{array}{l}\text { Nonriver } \\
\text { sand }\end{array}$ & $\begin{array}{c}\text { Thin layer for reserves } \\
\text { Nonreserve layer } \\
\text { (Biaowai layer) }\end{array}$ & $H<1.0 \mathrm{~m}$ & $<100$ & $\begin{array}{c}\text { Typically formation is sheeted } \\
\text { broken like, loose, small size, } \\
\text { two-phase mixed staggered } \\
\text { distribution }\end{array}$ \\
\hline
\end{tabular}

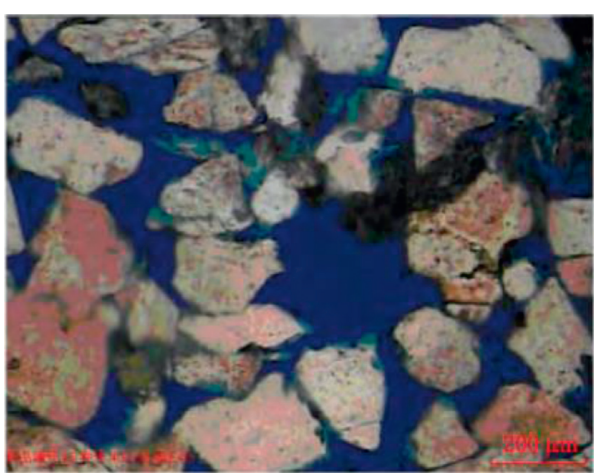

(a)

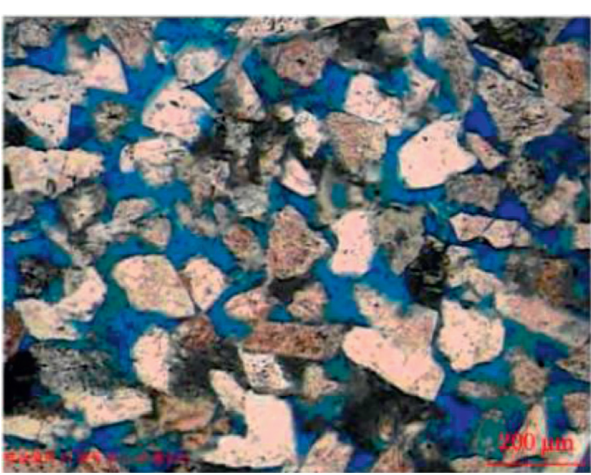

(b)

FIgURE 3: The polarized light micrograph of reservoir core [77]: (a) FCL; (b) SCL.

TABLE 3: Pore structure parameter of FCL and SCL in Daqing Oilfield [72]].

\begin{tabular}{|c|c|c|c|c|c|c|c|c|c|}
\hline No. & $\begin{array}{c}\text { Sample } \\
\text { no. }\end{array}$ & $\begin{array}{c}\text { Throat } \\
\text { mercury } \\
\text { saturation }(\%)\end{array}$ & $\begin{array}{l}\text { Pore mercury } \\
\text { saturation (\%) }\end{array}$ & $\begin{array}{l}\text { Mean pore } \\
\text { radius } \\
(\mu \mathrm{m})\end{array}$ & $\begin{array}{c}\text { Mean } \\
\text { throat } \\
\text { radius } \\
(\mu \mathrm{m})\end{array}$ & $\begin{array}{c}\text { Mean pore- } \\
\text { throat } \\
\text { radius ratio }\end{array}$ & $\begin{array}{l}\text { Microhomogeneity } \\
\text { coefficient }\end{array}$ & $\begin{array}{l}\text { Sorting } \\
\text { coefficient }\end{array}$ & $\begin{array}{l}\text { Main } \\
\text { throat } \\
\text { radius }\end{array}$ \\
\hline 1 & FCL 1 & 25.06 & 51.89 & 242.12 & 15.433 & 18.6 & 0.702 & 1.799 & 13.463 \\
\hline 2 & FCL 2 & 28.44 & 56.6 & 195.77 & 10.907 & 21.3 & 0.545 & 2.216 & 19.856 \\
\hline \multicolumn{2}{|c|}{ Average } & 26.75 & 54.245 & 218.945 & 13.17 & 19.95 & 0.6235 & 2.0075 & 16.6595 \\
\hline 3 & SCL 1 & 33.91 & 30.66 & 166.11 & 8.231 & 32.9 & 0.633 & 2.482 & 7.261 \\
\hline 4 & SCL 2 & 28.11 & 35.15 & 168.85 & 9.327 & 34.4 & 0.717 & 3.127 & 9.127 \\
\hline 5 & SCL 3 & 33.06 & 31.93 & 161.1 & 8.287 & 32.3 & 0.592 & 2.551 & 7.331 \\
\hline 6 & SCL 4 & 48.96 & 28.12 & 129.48 & 8.155 & 35.7 & 0.627 & 2.861 & 7.403 \\
\hline \multicolumn{2}{|c|}{ Average } & 36.0 & 31.5 & 156.4 & 8.5 & 33.8 & 0.6 & 2.8 & 7.8 \\
\hline
\end{tabular}

TABLE 4: SASP granularity analysis data from checking wells.

\begin{tabular}{|c|c|c|c|c|c|c|}
\hline Layers & Big sand content $(\%)$ & Fine sand content (\%) & Silt content (\%) & Clay content (\%) & Sorting coefficient & Median size $(\mathrm{mm})$ \\
\hline SII3-4 & 1.0 & 49.8 & 37.7 & 9.7 & 3.0 & 0.105 \\
\hline SII7-8 & 21.1 & 49.0 & 21.3 & 8.6 & 3.6 & 0.161 \\
\hline SII8-9 & & 20.1 & 66.1 & 13.8 & 4.1 & 0.062 \\
\hline SII8-9 & 5.2 & 48.9 & 35.3 & 9.0 & 3.3 & 0.117 \\
\hline Average & 9.1 & 42.0 & 40.1 & 10.3 & 3.5 & 0.111 \\
\hline
\end{tabular}


TABLE 5: WASP granularity analysis data from checking wells.

\begin{tabular}{lcccccc}
\hline Layer & $\begin{array}{c}\text { Average air permeability } \\
\left(\mu \mathrm{m}^{2}\right)\end{array}$ & $\begin{array}{c}\text { Fine sand content } \\
(\%)\end{array}$ & $\begin{array}{c}\text { Silt content } \\
(\%)\end{array}$ & $\begin{array}{c}\text { Clay content } \\
(\%)\end{array}$ & $\begin{array}{c}\text { Sorting } \\
\text { coefficient }\end{array}$ & $\begin{array}{c}\text { Median size } \\
(\mathrm{mm})\end{array}$ \\
\hline $\begin{array}{l}\text { Reserved layer } \\
\begin{array}{l}\text { Unreserved } \\
\text { layer }\end{array}\end{array}$ & 0.365 & 38.6 & 47.6 & 13.8 & 3.0 & 0.088 \\
\hline
\end{tabular}

TABLE 6: Clay minerals from one well in SASP.

\begin{tabular}{lccccc}
\hline Item & Smectite (S) & Illite (I) & Kaolinite (K) & Chlorite (C) & Imon mixed layer (I/S) \\
\hline Content (\%) & 1.41 & 29.67 & 47.95 & 13.83 & 7.35 \\
\hline
\end{tabular}

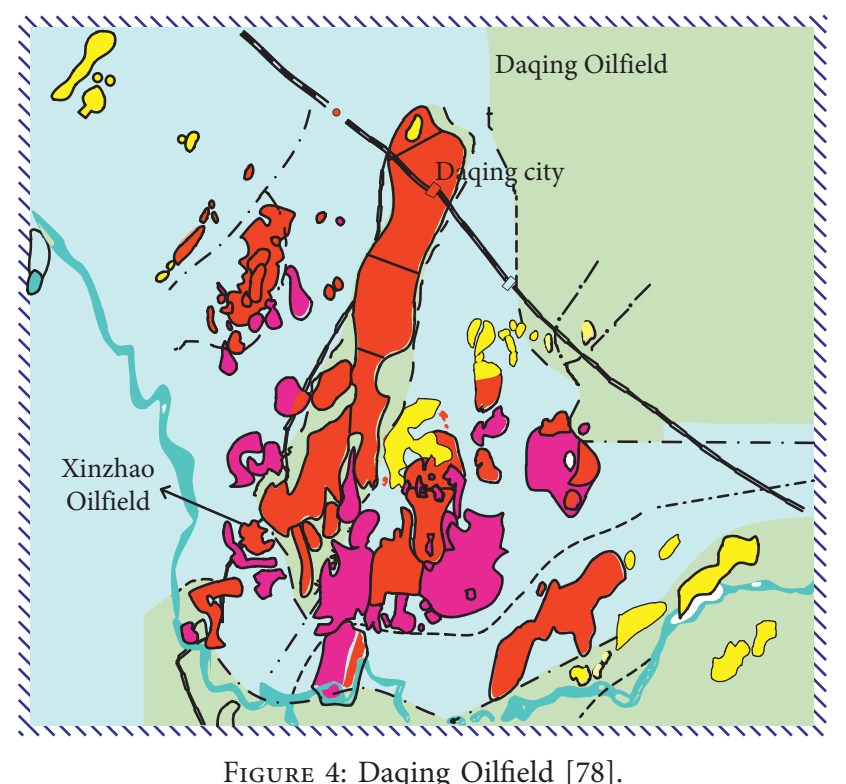

related to the difference between different crude oils, especially the definition of pectin and asphaltenes, and the separation method.

Deep understanding of this issue requires further study [60]. The crude oil composition of the two blocks is shown in Table 11 [84]. The content of pectin and asphaltene in B-2-X is higher than that in B-1-D, which is beneficial for reducing the interfacial tension. It is worth mentioning that the wax content in crude oil in S formation in Daqing is relatively high. The wax content of the dead oil is $29.61 \%$, and the freezing point is $22.55^{\circ} \mathrm{C}$. The total acid number (TAN) of crude oil in both test areas is very low, which makes it difficult to select for surfactants. The TAN of Daqing oil was so low that it was once believed impossible to employ ASP flooding according to preliminary screening report by some experts. For Daqing crude oil, when alkali is not added, the surfactant and crude oil cannot form ultralow IFT $\left(10^{-3} \mathrm{mN} /\right.$ $\mathrm{m})$. After adding alkali, ultralow interfacial tension can be attained. Figure 8 [80] shows the ASP system interface activity diagram for two field tests. The figure shows that the ASP system can form ultralow IFT with crude oil at surfactant concentration $(0.3 \%)$ and alkali concentration $(1.2 \%)$. The surfactants used in these two blocks were produced locally in Daqing. SASP used heavy oil alkybenzoyl sulfonate (HABS), while WASP used Daqing petroleum sulfonate (DPS), which was not as mature as the HABS technology then. However, the performance of the surfactant fully meets the requirements of Daqing Oilfield. More information on surfactants and field tests in Daqing Oilfield is given in our publication [85]. Table 12 shows the crude oil properties of the two test areas. Table 13 [84] shows the injected water composition of the tests, where produced water was used to prepare polymers after simple treatment. The content of calcium and magnesium ions in the injected water in WASP was slightly higher than that in SASP, but both were relatively low. Table 14 [86] shows the composition of the formation water in Daqing Oilfield, which provides valuable information when conducting ASP elsewhere. There are many publications regarding chemical EOR about Daqing Oilfield, but the detailed information about brine and oil is seldom provided.

\section{Injection Scheme}

In both tests were employed four slug design. During the implementation of the plan, dynamic adjustments were made according to the actual situation. The plan and the actual plan are different. Details are shown in Tables 15 and 16. The implementation plan adopted the same technical standards and received review and technical guidance of experts from Daqing Oilfield and China National Petroleum Corporation (CNPC). The operators of the two test areas are from different oil production plants of Daqing Oilfield. For more ideas on viscosity selection and fluidity control of the ternary compound flooding in Daqing Oilfield, please refer to the literature $[25,26,33,56,57,67,68,87-94]$. The ASP formulas used in the two tests are as follows.

Tables 15 and 16 show that these two tests have very similar injection parameters. For instance, the surfactant (S) and alkali (A) concentration are the same. Designed four slugs are the same. According to previous introduction, ultralow IFT is required for both ASP chemicals. WASP has a slight lower polymer concentration in ASP main slug and vice slug, while its preslug polymer concentration is a bit higher. Injection viscosity in SASP is a bit higher than WASP. However, the largest difference between these two tests is alkali. Strong alkali $\mathrm{NaOH}$ is used in SASP, while weak alkali $\mathrm{Na}_{2} \mathrm{CO}_{3}$ is used in WASP. The other big 


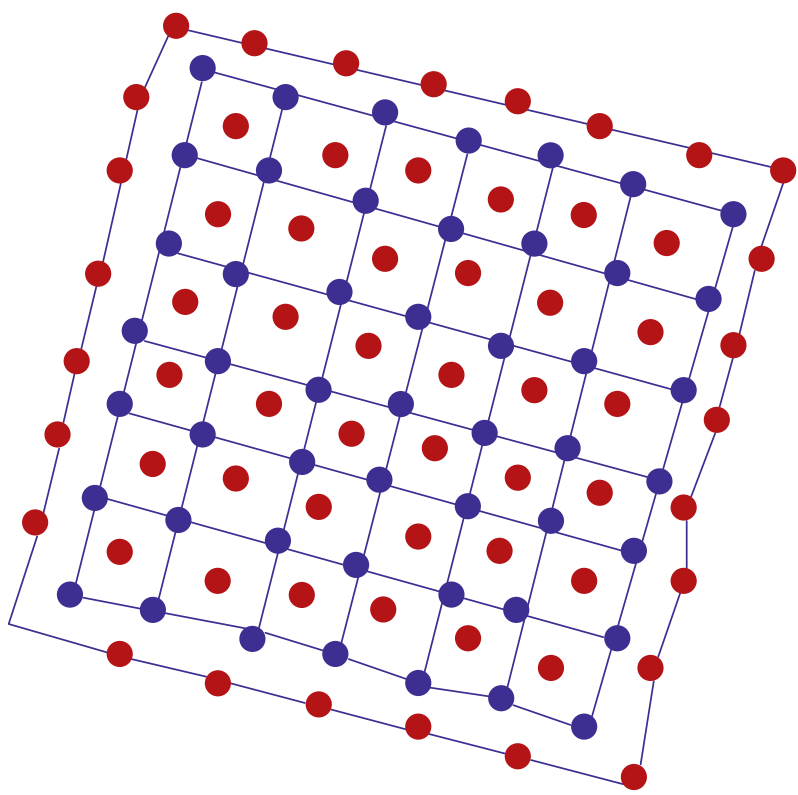

(a)

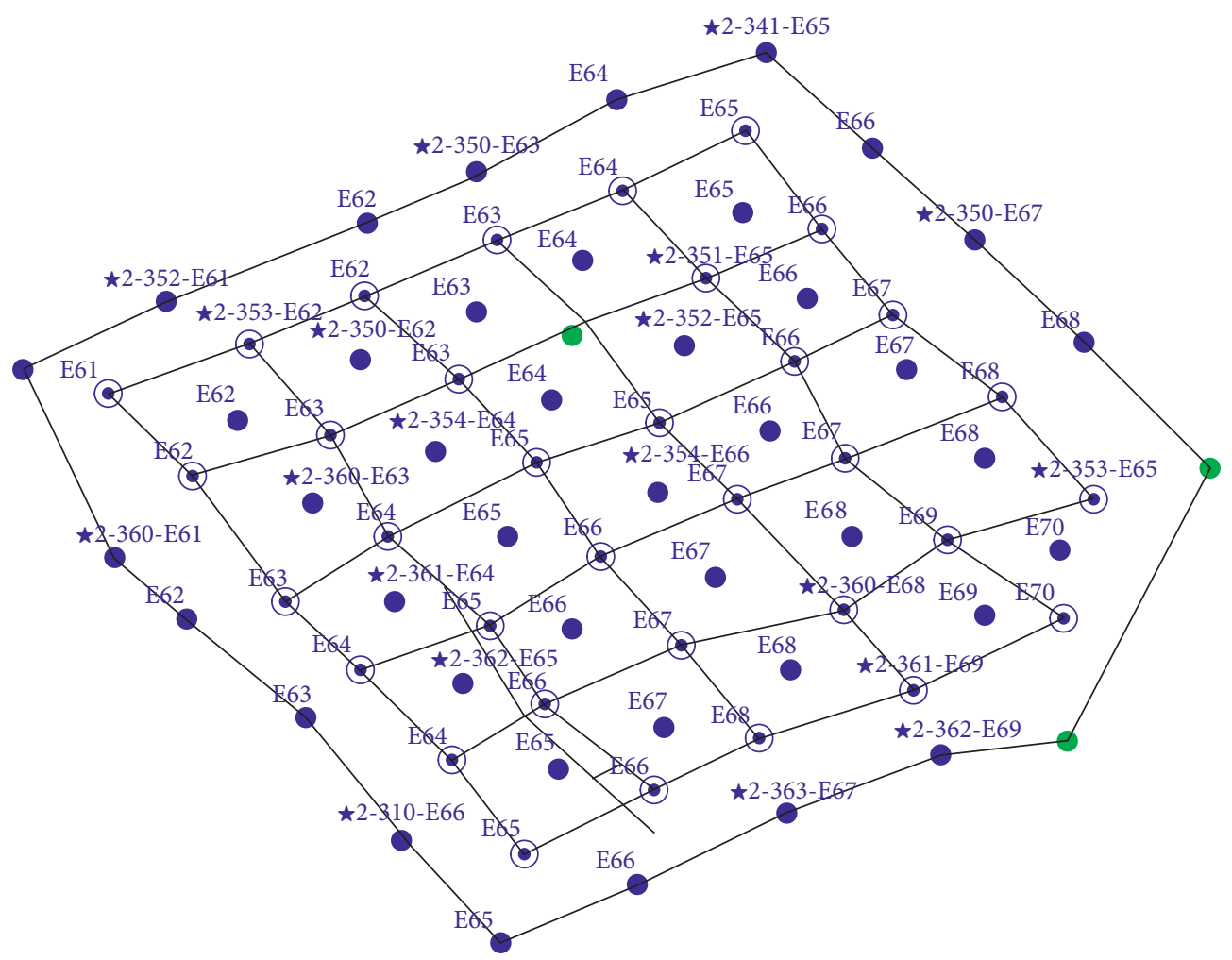

(b)

Figure 5: ASP flooding test well pattern [80, 81]. (a) SASP. (b) WASP.

difference is surfactant. Heavy-oil alkybenzoyl sulfonate (HABS) is used in B-1-D while Daqing petroleum sulfonate (DPS) is used in B-2-X. Both injected ASP can attain ultralow IFT between Daqing oil and water. If ultralow IFT is attained, the surfactant difference is not big according to capillary number theory.

\section{Production Performance}

Chemical injection at different stages is shown in Tables 17 and 18. Average chemical injection rate of SASP and WASP is $0.18 \mathrm{PV}$ per year $(\mathrm{PV} / \mathrm{a})$ and $0.23 \mathrm{PV} / \mathrm{a}$. Injection rate in $\mathrm{B}-2-\mathrm{X}$ is higher than B-1-D. Different from B-2-X where mainly 25 million molecular weight $(\mathrm{Mw})$ is used from the 


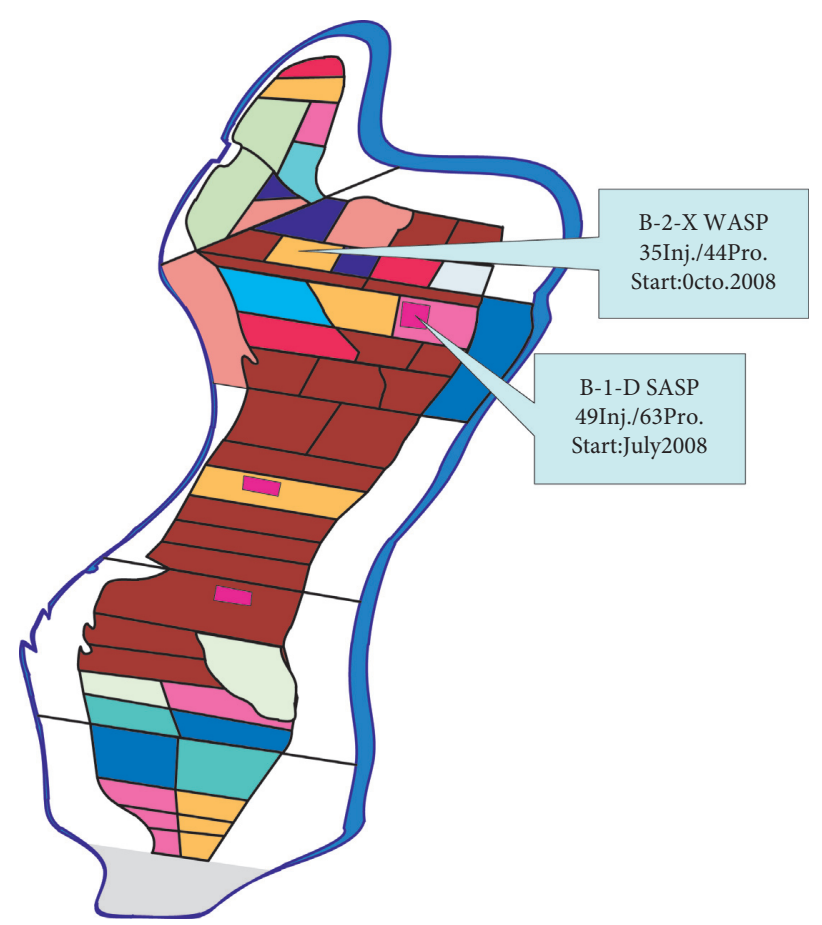

Figure 6: B-1-D and B-2-X location in Daqing [40].

TABLE 7: B-1-D sediment unit [72].

\begin{tabular}{|c|c|c|c|}
\hline No. & Deposition type & Sublayers & Unit number \\
\hline 1 & Distributary plain sand body with low bending distributary & $\mathrm{SII}^{1}, \mathrm{SII}^{2}, \mathrm{SII}^{1}$ & 3 \\
\hline 2 & Distributary plain facies direct distributary sand body & SII7, SII $8^{2}$ & 2 \\
\hline 3 & Delta front facies with lump-like sand & SII1, SII3, SII4, SII5+6 ${ }^{1}$, SII5+6 ${ }^{2}$ & 5 \\
\hline 4 & Leading edge dendritic transitional sand body in the delta & SII9 & 1 \\
\hline & In total & \multicolumn{2}{|l|}{11} \\
\hline
\end{tabular}

TABLE 8: SASP perforated layer thickness and permeability distribution [72].

\begin{tabular}{|c|c|c|c|c|c|}
\hline \multirow[t]{2}{*}{ Number } & \multirow[t]{2}{*}{ Sublayer } & \multicolumn{2}{|c|}{$\begin{array}{l}\text { Average perforation } \\
\text { thickness }(\mathrm{m})\end{array}$} & \multirow[t]{2}{*}{ Perforated layer thickness ratio (\%) } & \multirow[t]{2}{*}{ Effective permeability(D) } \\
\hline & & Sandstone & Effective & & \\
\hline 1 & SII1 & 0.03 & 0.02 & 0.3 & 0.159 \\
\hline 2 & SII21 & 1 & 0.6 & 7.9 & 0.466 \\
\hline 3 & SII22 & 1.2 & 0.8 & 10.7 & 0.548 \\
\hline 4 & SII3 & 0.3 & 0.2 & 3.1 & 0.515 \\
\hline 5 & SII4 & 1 & 0.6 & 8 & 0.499 \\
\hline 6 & $\operatorname{SII} 5+6^{1}$ & 0.4 & 0.2 & 3.2 & 0.629 \\
\hline 7 & $\operatorname{SII} 5+6^{2}$ & 0.2 & 0.1 & 1.2 & 0.489 \\
\hline 8 & SII7 & 1.6 & 1.3 & 16.4 & 0.663 \\
\hline 9 & SII8 ${ }^{1}$ & 2.7 & 2.2 & 28 & 0.766 \\
\hline 10 & SIII $8^{2}$ & 1.8 & 1 & 13.5 & 0.754 \\
\hline 11 & SII9 & 0.8 & 0.6 & 7.7 & 0.769 \\
\hline Sum & 10.6 & \multicolumn{2}{|c|}{7.7} & 100 & 0.67 \\
\hline
\end{tabular}

TABLE 9: B-2-X sediment unit [74].

\begin{tabular}{|c|c|c|c|}
\hline Number & Deposition type & Number of units & Sublayers \\
\hline 1 & Twig transitional delta deposition & 1 & SII9 \\
\hline 2 & Low-bend tributary plain facies delta deposition & 3 & SII10 + 11a, SII10 + 11b, SII12 \\
\hline 3 & Delta deposition with subtree front & 1 & $\operatorname{SII} 13+14 \mathrm{a}$ \\
\hline 4 & Delta deposition with lump front & 1 & SII $13+14 b$ \\
\hline
\end{tabular}


TABLE 10: B-2-X perforation thickness and permeability distribution [74].

\begin{tabular}{lcccc}
\hline No. & Sublayer & $\begin{array}{c}\text { Average perforation thickness }(\mathrm{m}) \\
\text { Sandstone }\end{array}$ & Effective & Effective permeability (D) \\
\hline 1 & SII10 +11a & 2.47 & 1.92 & 0.423 \\
2 & SII10 + 11b & 2.49 & 2.08 & 0.504 \\
3 & SII12 & 2.70 & 2.29 & 0.570 \\
& In total & 7.66 & 6.29 & 0.503 \\
\hline
\end{tabular}

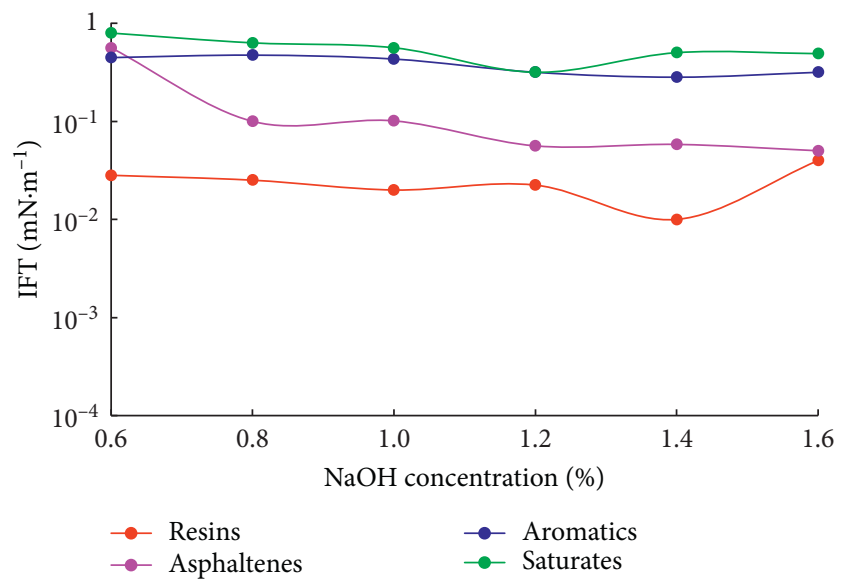

Figure 7: IFT affected by different oil groups [83].

TABLe 11: Oil composition comparison [84].

\begin{tabular}{|c|c|c|c|c|c|c|c|}
\hline Block & Total hydrocarbons & $\begin{array}{c}\text { Saturated } \\
\text { hydrocarbon }\end{array}$ & $\begin{array}{c}\text { Aromatic } \\
\text { hydrocarbon }\end{array}$ & Pectin & Asphaltene & Pectin + asphaltene & TAN, mgKOH/g \\
\hline SASP & 81.83 & 69.12 & 12.71 & 13.16 & 5.01 & 18.17 & 0.031 \\
\hline WASP & 76.97 & 64.84 & 12.13 & 16.39 & 6.64 & 23.03 & 0.034 \\
\hline
\end{tabular}

beginning to the end, three different $\mathrm{Mw}(15,19$, and 25 million Dalton) polymers are used in B-1-D. The slug viscosity of SASP in B-1-D increased correspondingly. However, during ASP vice slug in B-1-D, the ASP slug viscosity was reduced from $72 \mathrm{cP}$ to $48 \mathrm{cP}$. This was not scheduled. Since polymer viscoelasticity benefit to recovery was very popular in China at that time, it is unusual to reduce viscosity unless they have to. This is actually due to some injectivity problems as well as too much production ability reduction. This will be discussed later. The most significant difference between implementation is reference water flooding (RW) injection. In B-1-D, $0.095 \mathrm{PV}$ water slug is injected. However, $0.7236 \mathrm{PV}$ water slug was injected in B-2$\mathrm{X}$. This has very significant influence on the incremental oil recovery factor (IORF). Water cut after reference water flooding of SASP and WASP was $95.2 \%$ and $98.7 \%$, respectively [81]. The water cut difference is actually very large according to actual oil production practice in Daqing since these are large-scale blocks. Since water cut in B-2-X is much higher than B-1-D before chemical flooding started, only when IORF of SASP is much higher than WASP, and SASP can be regarded better than WASP in terms of IORF. This will be discussed more later. Table 19 shows average well production in these two blocks. It is obvious that average well production rate of WASP is lower than SASP but the increase is larger.

6.1. Injection Pressure. The average injection pressure during different stages of the two blocks is shown in Figure 9. At the end of the reference water flooding, the average single well daily injection volume in B-1-D is $57 \mathrm{~m}^{3}$, and the average injection pressure and formation pressure are $7.96 \mathrm{MPa}$ and $5.92 \mathrm{MPa}$, respectively $[80,81]$. When RW finished, the single well daily average injection volume in B-2-X is $42 \mathrm{~m}^{3}$, the average single well injection pressure is $4.92 \mathrm{MPa}$, and the formation pressure is $7.55 \mathrm{MPa}$. This indicated that water injectivity ability of $\mathrm{B}-2-\mathrm{X}$ is smaller than $\mathrm{B}-1-\mathrm{D}$. At the end of RW, the injection pressure of B-1-D is lower than B-2-X, which may be related to the average permeability. Permeability especially the average effective permeability of the main water-absorbing layer (SII7, SII8 ${ }^{1}, \mathrm{SII}^{2}{ }^{2}$ ) of B-1-D is $0.7 \mu \mathrm{m}^{2}$, which is significantly higher than that of $\mathrm{B}-2-\mathrm{X}$. In addition, water flooding injection pressure is also related to water cut, but the effect of permeability on the difference in injection pressure is greater than the effect of water cut. In chemical flooding stage (polymer and ASP injection), the formation pressure increased due to the increased viscosity 


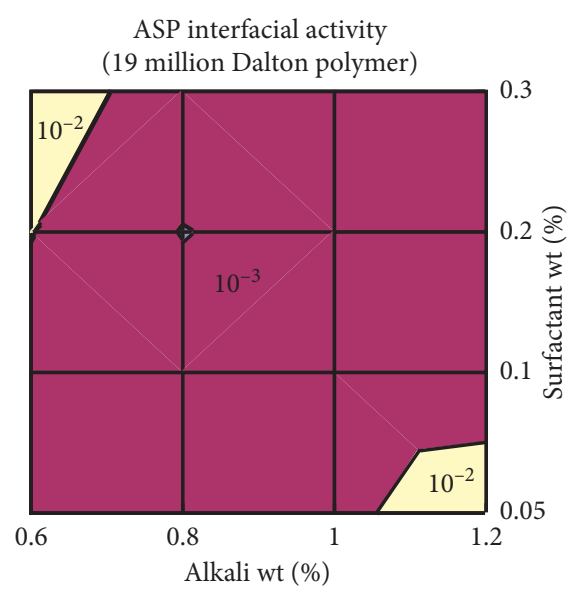

(a)

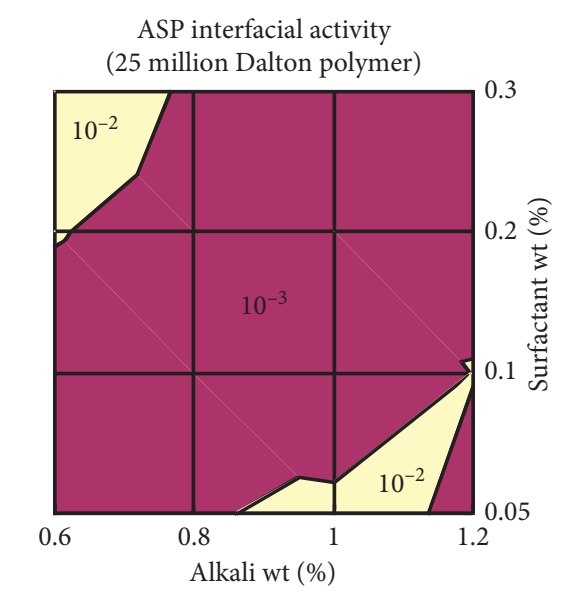

(b)

ASP interfacial activity (25 million Dalton polymer)

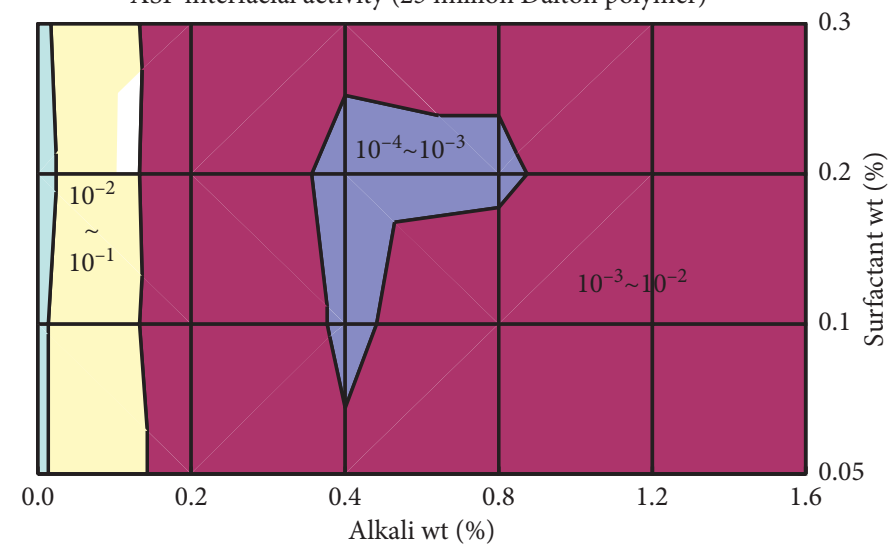

(c)

FIgURE 8: IFT diagram comparison [80]. (a) SASP interface activity, 19 million Dalton polymer; (b) SASP interface activity, 25 million Dalton polymer; (c) WASP interface activity, 25 million Dalton polymer.

TABLE 12: Dead oil physical feature comparison.

\begin{tabular}{lccccccccc}
\hline $\begin{array}{l}\text { Oil } \\
\text { layer }\end{array}$ & $\begin{array}{c}\text { Density } \\
\left(\mathrm{g} / \mathrm{cm}^{3}\right)\end{array}$ & $\begin{array}{c}\text { Viscosity } \\
(\mathrm{mPa})\end{array}$ & $\begin{array}{c}\text { Freezing } \\
\text { point }\left({ }^{\circ} \mathrm{C}\right)\end{array}$ & $\begin{array}{c}\text { Wax } \\
\text { content } \\
(\%)\end{array}$ & $\begin{array}{c}\text { Resin } \\
\text { content }(\%)\end{array}$ & $\begin{array}{c}\text { Sulfur } \\
\text { content }(\%)\end{array}$ & $\begin{array}{c}\text { Original gas-oil } \\
\text { ratio }\left(\mathrm{m}^{3} / t\right)\end{array}$ & $\begin{array}{c}\text { Volume } \\
\text { factor }\end{array}$ & $\begin{array}{c}\text { Saturation } \\
\text { pressure }(\mathrm{MPa})\end{array}$ \\
\hline SASP & 0.864 & 23.5 & 24.8 & 17.01 & 21.41 & 0.07 & 47.9 & 1.07 & 9.5 \\
WASP & 0.865 & $16.6-90.0$ & $22-30$ & $20.1-32$ & 23.03 & $<0.2$ & $47.4-50$ & 1.12 & $9.77-10.69$ \\
\hline
\end{tabular}

TABLE 13: Injection water comparison.

\begin{tabular}{|c|c|c|c|c|c|c|c|c|c|}
\hline Block & $\mathrm{Ca}^{2+}, \mathrm{mg} / \mathrm{L}$ & $\mathrm{Mg}^{2+}, \mathrm{mg} / \mathrm{L}$ & $\mathrm{Cl}, \mathrm{mg} / \mathrm{L}$ & $\mathrm{HCO}_{3}{ }^{-}, \mathrm{mg} / \mathrm{L}$ & $\mathrm{CO}_{3}{ }^{2-}, \mathrm{mg} / \mathrm{L}$ & $\mathrm{SO}_{4}{ }^{2-}, \mathrm{mg} / \mathrm{L}$ & $\mathrm{K}^{+}+\mathrm{Na}^{+}, \mathrm{mg} / \mathrm{L}$ & TDS, mg/L & $\mathrm{pH}$ \\
\hline SASP & 37.17 & 10.33 & 832.8 & 2226.39 & 289.66 & NA & 1549.83 & 4968.18 & 7.97 \\
\hline WASP & 40.1 & 12.2 & 895.1 & 3065.2 & 63.1 & 6 & 1718.4 & 5800.1 & 8.4 \\
\hline
\end{tabular}

TABle 14: Daqing formation brine composition [86]].

\begin{tabular}{|c|c|c|c|c|c|c|c|c|c|c|}
\hline Layer & $\mathrm{pH}$ & $\mathrm{CO}_{3}{ }^{2-}, \mathrm{mg} / \mathrm{L}$ & $\mathrm{HCO}_{3}{ }^{-}, \mathrm{mg} / \mathrm{L}$ & $\mathrm{Cl}, \mathrm{mg} / \mathrm{L}$ & $\mathrm{SO}_{4}{ }^{2-}, \mathrm{mg} / \mathrm{L}$ & $\mathrm{Ca}^{2+}, \mathrm{mg} / \mathrm{L}$ & $\mathrm{Mg}^{2+}, \mathrm{mg} / \mathrm{L}$ & $\mathrm{K}^{+}, \mathrm{mg} / \mathrm{L}$ & $\mathrm{Na}^{+}, \mathrm{mg} / \mathrm{L}$ & TDS, mg/L \\
\hline$S$ & 8.42 & 139.33 & 1342.62 & 2363.87 & 66.34 & 25.39 & 9.44 & 49.43 & 2091.06 & 6037.88 \\
\hline $\mathrm{P}$ & 8.30 & 183.30 & 2285.74 & 3299.08 & 280.21 & 35.97 & 9.07 & 217.56 & 2982.04 & 9234.84 \\
\hline
\end{tabular}


TABle 15: Designed ASP scheme.

\begin{tabular}{|c|c|c|c|c|c|c|c|c|c|c|}
\hline \multirow{3}{*}{ Test } & \multirow{3}{*}{$\begin{array}{l}\text { Pre-slug concentration } \\
\quad(\mathrm{mg} / \mathrm{L}) 0.0375 \mathrm{PV}\end{array}$} & \multirow{2}{*}{\multicolumn{3}{|c|}{$\begin{array}{c}\text { ASP main slug } \\
0.3 \mathrm{PV}\end{array}$}} & \multicolumn{3}{|c|}{ ASP vice slug } & \multirow{3}{*}{$\begin{array}{l}\text { Post P slug concentration } \\
(\mathrm{mg} / \mathrm{L}) 0.2 \mathrm{PV}\end{array}$} & \multirow{3}{*}{$\begin{array}{l}\text { Injection rate } \\
(\mathrm{PV} / \mathrm{a})\end{array}$} & \multirow{3}{*}{$\begin{array}{l}\text { Predicted IORF } \\
\quad(\% \text { OOIP })\end{array}$} \\
\hline & & & & & \multicolumn{3}{|c|}{$0.15 \mathrm{PV}$} & & & \\
\hline & & $\begin{array}{c}\mathrm{A} \\
(\%)\end{array}$ & $\begin{array}{c}\mathrm{S} \\
(\%)\end{array}$ & $\begin{array}{c}\mathrm{P} \\
(\mathrm{mg} / \mathrm{L})\end{array}$ & $\begin{array}{c}\mathrm{A} \\
(\%)\end{array}$ & $\begin{array}{c}S \\
(\%)\end{array}$ & $\begin{array}{c}\mathrm{P} \\
(\mathrm{mg} / \mathrm{L}) \\
\end{array}$ & & & \\
\hline SASP & 1300 & 1.2 & 0.3 & 2000 & 1 & 0.1 & 1800 & 1000 & 0.2 & 21.7 \\
\hline WASP & 1350 & 1.6 & 0.3 & 1800 & 1.4 & 0.1 & 1800 & 1350 & 0.2 & 22.2 \\
\hline
\end{tabular}

TABle 16: Actual injection scheme.

\begin{tabular}{|c|c|c|c|c|c|c|c|c|c|c|c|c|}
\hline & \multicolumn{2}{|c|}{ Preslug } & \multicolumn{4}{|c|}{ ASP main slug } & \multicolumn{4}{|c|}{ ASP vice slug } & \multicolumn{2}{|c|}{ Postslug } \\
\hline & $\begin{array}{l}\text { Size } \\
(\mathrm{PV})\end{array}$ & $\begin{array}{c}\mathrm{P} \\
(\mathrm{mg} / \mathrm{L})\end{array}$ & $\begin{array}{l}\text { Size } \\
(\mathrm{PV})\end{array}$ & $\begin{array}{c}\text { A } \\
(\%)\end{array}$ & $\begin{array}{c}\text { S } \\
(\%)\end{array}$ & $\begin{array}{c}\mathrm{P} \\
(\mathrm{mg} / \mathrm{L})\end{array}$ & $\begin{array}{l}\text { Size } \\
\mathrm{PV}\end{array}$ & $\begin{array}{c}\text { A } \\
(\%)\end{array}$ & $\begin{array}{c}\text { S } \\
(\%) \\
\end{array}$ & $\begin{array}{c}\mathrm{P} \\
(\mathrm{mg} / \mathrm{L})\end{array}$ & $\begin{array}{l}\text { Size } \\
(\mathrm{PV})\end{array}$ & $\begin{array}{c}\mathrm{P} \\
(\mathrm{mg} / \mathrm{L}) \\
\end{array}$ \\
\hline SASP & 0.054 & 1300 & 0.351 & 1.2 & 0.3 & 2000 & 0.285 & 10.8 & 0.20 .1 & 2000 & 0.233 & 1500 \\
\hline WASP & 0.0801 & 1350 & $0.4284(0.3501)$ & 1.2 & 0.3 & 17501980 & 0.2203 & 1.0 & 0.1 & 19401980 & 0.25 & 1500 \\
\hline
\end{tabular}

TABLE 17: SASP time table.

\begin{tabular}{lcccc}
\hline Stage & Time & Polymer Mw (million Dalton) & Well head viscosity (cP) & Slug size (PV) \\
\hline RW & $12.2005-06.2006$ & - & - & 30 \\
Prepolymer & $07.2006-10.2006$ & 15 & 31 & 0.095 \\
ASP main & $11.2006-06.2007$ & 15 & 65 & 0.054 \\
ASP main & $07.2007-12.2007$ & 19 & 77 & 0.108 \\
ASP main & $01.2008-12.2008$ & 25 & $72-48$ & 0.084 \\
ASP vice & $01.2009-04.2010$ & 25 & $52-63$ & 0.285 \\
Postpolymer & $05.2010-12.2011$ & 25 & 0.233 \\
\hline
\end{tabular}

TABLe 18: WASP time table.

\begin{tabular}{lcccc}
\hline Stage & Time & Polymer Mw (Million Dalton) & Well head viscosity (cP) & Slug size (PV) \\
\hline RW & $11.2005-10.2008$ & - & - & 22 \\
Prepolymer & $10.2008-03.2009$ & 25 & 58 & 0.7236 \\
ASP main & $03.2009-05.2011$ & 25 & 60 & 0.0801 \\
ASP vice & $05.2011-03.2012$ & 25 & 69 & 0.2203 \\
Postpolymer & $03.2012-04.2013$ & 25 & 0.2384 \\
\hline
\end{tabular}

TABle 19: Average well production comparison.

\begin{tabular}{lccccc}
\hline Block & Water & Prepolymer & ASP main & ASP vice & Postpolymer \\
\hline SASP & 2.3 & 2.7 & 9 & 5.5 & 4.4 \\
WASP & 1 & 0.75 & 8.86 & 5.68 & 4.11 \\
\hline
\end{tabular}

and the adsorption and retention of the injected polymer molecules in the formation. In the stage of chemical flooding, the average pressure in B-1-D is significantly higher than that in B-2-X, as shown in Figure 9. However, injection pressure in vice polymer injection is not much higher than that of main ASP slug. Note that 25 million Dalton polymer is injected in B-2-X while 15,19 , and 25 million Dalton polymer is injected in B-1-D. Four reasons are accounted for this. First, injection pressure increased too much in main ASP slug compared with prepolymer stage due to increased polymer viscosity. Second, during vice ASP slug, the injection viscosity of slug is reduced due to injectivity and fluid production ability loss. More importantly, many fracturing measures have been taken during
ASP injection stage to improve performance. Finally, scaling due to alkali may account for too much pressure increase during main ASP stage.

Compared with the reference water flooding, the maximum pressure increase in SASP and WASP was 109\% and $82 \%$, respectively, and the increase in the SASP was higher. Since the injection pressure is too high and the fluid production declined greatly, fracturing measures are adopted in ASP flooding tests. A total of 61 fracturing times and wells for producers were conducted in B-1-D, and the fracturing well ratio accounted for $96.8 \%$ of the total production wells. For central well area, 40 wells/times were fractured for producers, and the fracturing ratio reached $111 \%[80,81]$. In B-2-X, wells were fractured 19 wells/times, and the fracturing ratio of the production wells was $43.2 \%$. The number and proportion of fracturing wells in the B-2-X were significantly lower than that in B-1-D. The difference in fracturing ratios also proves that SASP is less injectable than WASP. Fracturing adds significant labor amount and costs. The average permeability in B-1-D is higher than that of B-2- 


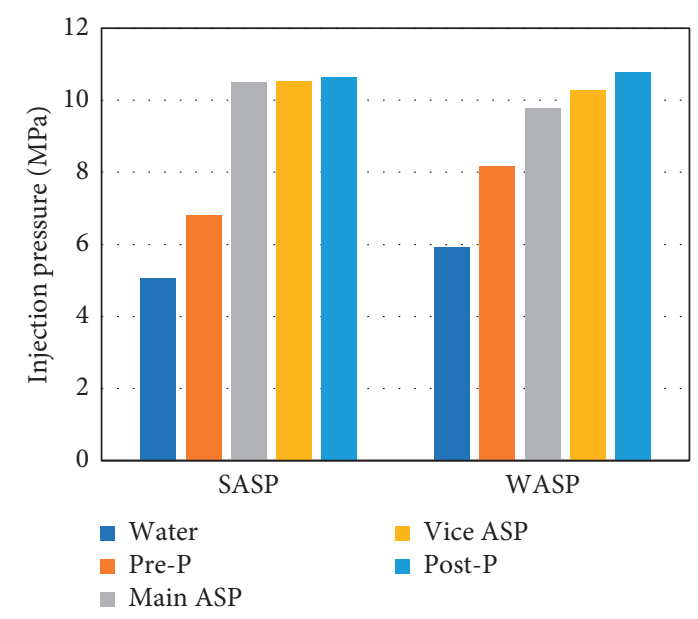

FIgURE 9: Injection pressure in different stages [41].

$\mathrm{X}$, but the injection rate is lower, and the average injection viscosity of main ASP slug in B-1-D is lower than that of B-2$\mathrm{X}$. Both have the same well pattern spacing, and scaling is a possible reason for the poor injection capacity. The polymer flooding and ASP flooding field tests under similar conditions in Daqing showed that before the main plug of the ASP flooding, the water absorption index is similar to that of the polymer flooding, sometimes even slightly higher, but the injection pressure after the ASP flooding significantly increases. Scaling and emulsification caused by alkali accounted for this. The injection pressure increase degree in SASP field tests was much higher than that in WASP $[80-82,84]$. Sealed coring analysis confirmed the formation of scale [95]. Laboratory experiments have also confirmed that the stronger emulsifying ability of strong alkali compared to weak alkali will also increase the injection pressure [56]. Two wells (27.7 $\mathrm{m}$ apart) were drilled and cored before and after one ASP flooding test in Daqing Oilfield. After injection of ASP, the cores' porosity and permeability decreased by $4.9 \%$ and $49.6 \%$, respectively, and median particle size decreased from $0.141 \mathrm{~mm}$ to $0.103 \mathrm{~mm}$ [96]. Other laboratory experiments $[51,52,55,65,97]$ have also confirmed the harmful effects of alkali on the reservoir, and the strong alkali has a greater harmful effect.

6.1.1. IORF. IORFs of these two tests are shown in Figure 10. As of October 2015, the injection of the chemical system has been completed in both test areas. B-1-D was cumulatively injected a chemical system of $0.937 \mathrm{PV}$, and IORF upon water flooding is $30 \%$ OOIP. B-2-X was cumulatively injected a chemical system of $0.910 \mathrm{PV}$, and the IORF is $29.4 \%$ OOIP [98]. The total recovery of B-1-D and B-2-X is $66.88 \%$ OOIP and $75.04 \%$ OOIP, respectively. Since the subsequent water flooding in both $\mathrm{B}-2-\mathrm{X}$ is still underway, the ultimate IORF of WASP is expected to exceed SASP. Considering that the injection timing of the two tests is different, the comprehensive water cut of whole test area at the end of the RW in B-1-D and B-2-X is $96.7 \%$ and $98.45 \%$, and the water cut in central well area is $95.2 \%$ and $98.8 \%$ OOIP, respectively

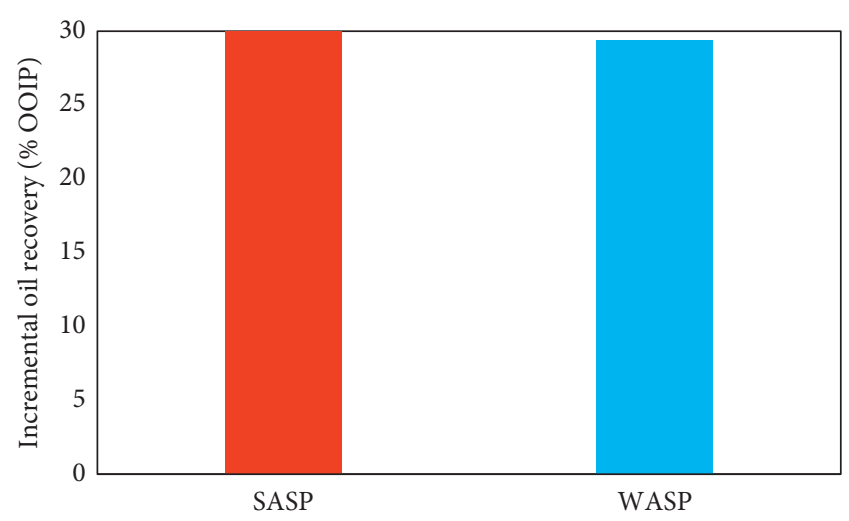

FIGURE 10: Incremental oil recovery factor.

[99]. Before chemical injection, the recovery of SASP and WASP was $36.88 \%$ and 45.64 OOIP\%, respectively [99].

A recovery difference of $8.76 \%$ OOIP between $B-1-D$ and $\mathrm{B}-2-\mathrm{X}$ is really great. The remaining oil or residual oil in $\mathrm{B}-2-$ $\mathrm{X}$ is more scatted, as verified by coring data analysis in $\mathrm{B}-2-\mathrm{X}$ [80], and it is thus more difficult to enhance oil recovery in B-2-X. Statistics of 12 ASP flooding field tests completed in Daqing Oilfield, combined with laboratory experiments and numerical simulations, show that the sooner the ASP is injected in high water cut stage, the better the effect [98]. In other words, since the water cut of SASP before the injection of the chemical is lower than that of WASP, IORF of SASP should have been much higher. Studies have shown that even if the comprehensive water cut is $0.5 \%$ different, for instance, $100 \%$ and $99.5 \%$, the displacement efficiency will be significantly different [100]. In respect of water cut difference and initial oil recovery, it can be considered that SASP and WASP have the same IORF, or even WASP IORF is higher.

6.2. High IORF Explanations. Full understanding of the reservoir geology is the foundation of possible high oil recovery. This is why we compared the two tests' geological information so much, which is quite different from other EOR publications. Geological characteristics and reservoir physical properties have a great impact on recovery and IORF. In this respect, we have previously compared the geological conditions of the two field tests in detail. From the geological situation, it can be seen that the deposition conditions and reservoir physical properties in B-1-D are significantly better than those in B-2-X, which are characterized by larger effective thickness, higher permeability, and good reservoir development. Daqing Oilfield test surveys show [95] that the greater the effective thickness of the formation, the better the development effect of the ASP. The polymer flooding in Daqing, which is currently the world's largest commercial polymer flooding block, has proven in practice that polymer connectivity factor or polymer controlling degree affects the polymer flooding effect [101]. Higher polymer flooding connectivity factor makes better IORF performance. Compared with the B-1$\mathrm{D}$, one advantage of $\mathrm{B}-2-\mathrm{X}$ is that the polymer flooding 
control degree $(90.02 \%)$ is a bit higher than that of B-1-D (86.7\%). However, according to the relationship between the polymer flooding control degree and IORF [101], when polymer flooding control degree is greater than $80 \%$, further increase in polymer flooding control degree has marginal effect on IORF. It can be considered that the difference in the polymer flooding control degree in two tests may have a limited impact on the range of IORF. However, it is important to note that many ASP flooding core flooding tests completed under Daqing Oilfield condition have shown that SASP IORF is greater than that of WASP [56]. In addition, the divalent ion content is very low in Daqing formation water (less than $50 \mathrm{pp}$ ). Thus, SASP flooding has been given more attention in the early time in Daqing $[25,26,33,67,88,91,92,94]$. The number of SASP flooding field tests is three times that of the weak alkali test area. Another main reason is that the production technology of low-cost surfactant for weak ASP flooding has not been mastered.

\section{Laboratory Study Limitations}

Compared with the WASP, due to the higher $\mathrm{pH}$ value, the strong alkali $(\mathrm{NaOH})$ has stronger emulsifying ability which forms more stable emulsion, and the IFT is lower $[61,97]$. Furthermore, the ability of $\mathrm{NaOH}$ to change wettability is also more prominent [24]. This makes $\mathrm{NaOH}$ perform better in laboratory evaluation and flooding experiments. With the progress of research, especially the better understanding of the mechanism of emulsification (moderate emulsification) and the formation of ultralow IFT of low-acid-based paraffin-based Daqing crude oil (average molecular equivalents and different effects of different components) [35] and scale and formation damage $[80,102-104]$, the researchers realized that although $\mathrm{NaOH}^{\prime}$ f fast interaction with crude oil can reduce the IFT, long-term effects of $\mathrm{Na}_{2} \mathrm{CO}_{3}$ interaction with crude oil will also form ultralow IFT. More importantly, $\mathrm{Na}_{2} \mathrm{CO}_{3}$ reduces the adsorption of surfactants and decreases the degree of polymer hydrolysis which helps to reduce the adsorption in the formation. The damage to the formation by $\mathrm{Na}_{2} \mathrm{CO}_{3}$ is not as large as that of $\mathrm{NaOH}$. In the core flooding tests in laboratory, the core's clay minerals are small due to the small scale. In addition, many synthetic cores used in China are different from real core in clay content, and it is difficult to effectively simulate the adverse effect of scaling on the displacement effect. The scale of laboratory experiments is too small to reflect the influence of clay minerals on scaling, and thus there are significant limitations in using cores to guide field applications $[51,52,55]$. The success of $\mathrm{B}-2-\mathrm{X}$ is far beyond researchers' expectations [25]. The other WASP test in B-3-X was also so technically and economically successful that it makes people to think whether SASP is really better than WASP.

\section{Key Observations}

More importantly, IORF of SASP in B-1-D is higher than all the other completed SASP in Daqing Oilfield. This is probably due to the high content of $\mathrm{CO}_{2}$ in B-1-D formation water, which makes the injected strong alkali $\mathrm{NaOH}$ transform into weak alkali $\mathrm{Na}_{2} \mathrm{CO}_{3}$. After ASP was injected into B-1-D, the concentration of carbonate $\left(\mathrm{CO}_{3}{ }^{2-}\right)$ and bicarbonate $\left(\mathrm{HCO}_{3}{ }^{-}\right)$in production wells continued to rise, and the content of $\mathrm{CO}_{2}$ in natural gas produced in this test area keeps dropping [80]. Different from other SASP field tests, no hydroxide $\left(\mathrm{OH}^{-}\right)$appeared in the production wells, which explained lack of alkali data in the production fluid [41]. Figure 11 [80] shows the $\mathrm{CO}_{2}$ content in the produced gas from three production wells and one inspection well in B-1-D. Figure 12 [80] shows the change of $\mathrm{CO}_{3}{ }^{2-}$ and $\mathrm{HCO}_{3}{ }^{-}$in the produced liquid in $\mathrm{B}-1-\mathrm{D}$, where the horizontal axis denotes time. 0607 represents "July 2006." This figure shows that after the ASP injection, $\mathrm{CO}_{2}$ in the formation is continuously consumed, and as the ASP slug injection ceases, $\mathrm{CO}_{2}$ is continuously generated. The cause of $\mathrm{CO}_{2}$ generation remains unclear and may be related to the formation pressure decrease. The effect of $\mathrm{CO}_{2}$ makes some or most strong alkali become weak alkali, thereby slowing down the scaling, which is reflected in the scaling ratio and scale-like composition changes. Proportion of silica scale in B-1-D is much lower than that of L-B-D and N-5 ASP flooding tests in Daqing which also employed $\mathrm{NaOH}$ as alkali [95]. This $\mathrm{CO}_{2}$ production and ion production observations provide key evidences to account for highest EOR performance in B-1-D. This also makes it possible to use $\mathrm{NaOH}$ as alkali for ASP flooding in $\mathrm{CO}_{2}$-rich reservoirs.

\section{Water Cut}

In the field test, the characteristics of water cut change are mainly affected by reservoir heterogeneity, injection-production well spacing, initial water cut, remaining oil, injection parameters, measures, and dynamic $g$ adjustments [95]. Interwell connectivity also has a greater impact on water cuts [101]. Among these complex factors, the relationship between water cut change and initial water cut is the easiest to verify and correlate. A comparison of water cut before and after chemical injection in central well area is shown in Figure 13. This figure shows that average water cut drop in B-1-D is much larger than WASP. However, the initial water cut in B-1-D is also much lower than B-2-X from actual production consideration. Minimum water cut in B-1-D is much lower than B-2-X, which indicated better production performance. Strong emulsification at least partly accounted for this. It is interesting that the water cut drop between two tests differs so much while IORF does not. The other key parameter about water cut is low water cut duration time. Low water cut duration time of SASP and WASP is 28 months and 25 months, respectively [60, 61]. SASP has a bit longer low water cut duration time. Considering its much more fracturing measures [52-55] during ASP flooding stage, this longer time cannot be regarded as evidence of SASP superiority. Field data [52-55] about these two tests indicated that higher oil saturation in B-1-D makes it quick to get possible response. Laboratory study verified that more emulsification and higher emulsion viscosity is seen where the initial water cut is lower and remaining oil saturation is higher for chemical flooding [98]. 


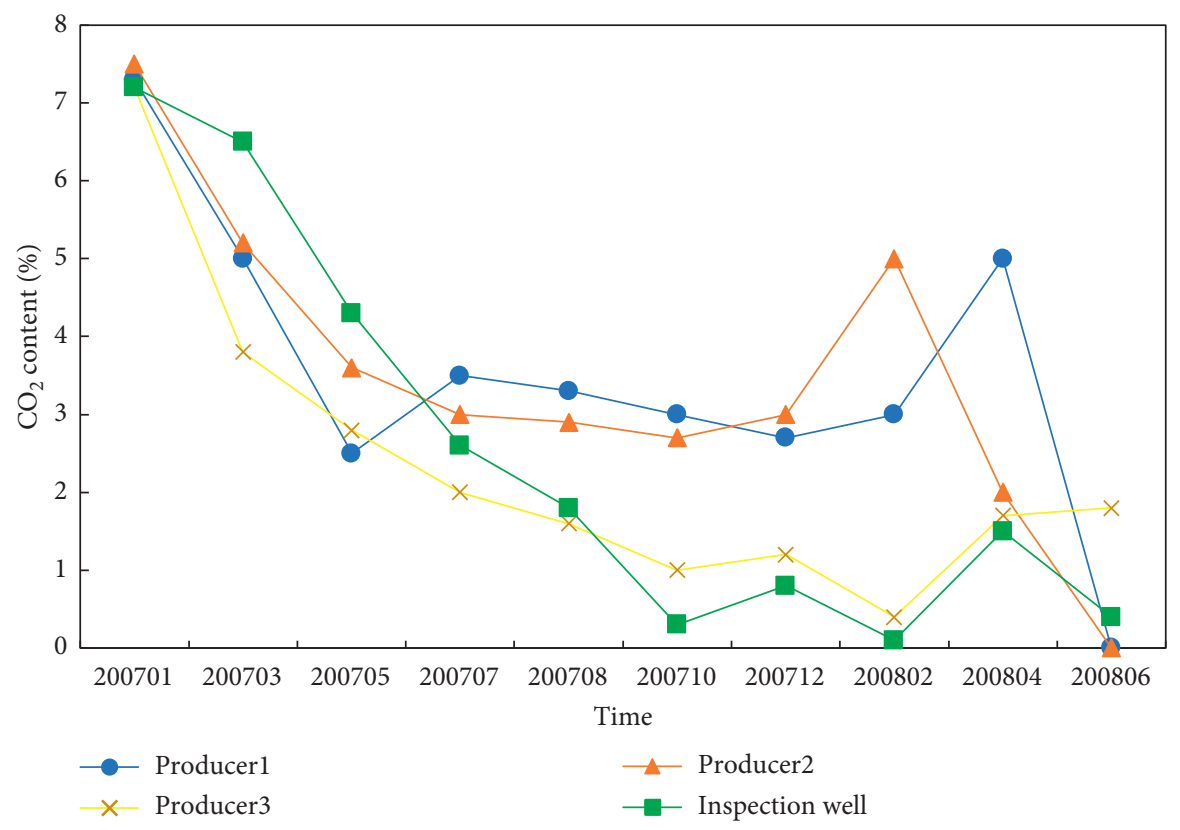

Figure 11: $\mathrm{CO}_{2}$ content in natural gas from B-1-D oil producers [80].

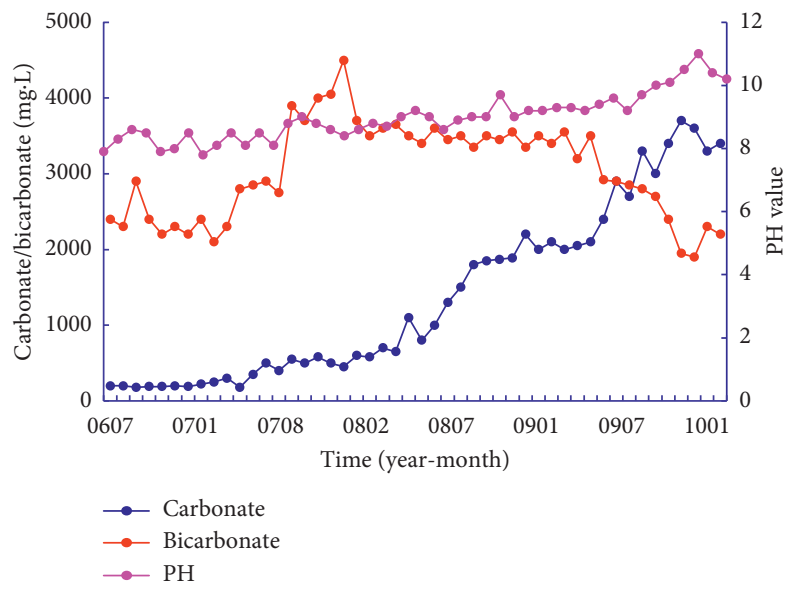

FIGURE 12: SASP produced fluid ion concentration [80].

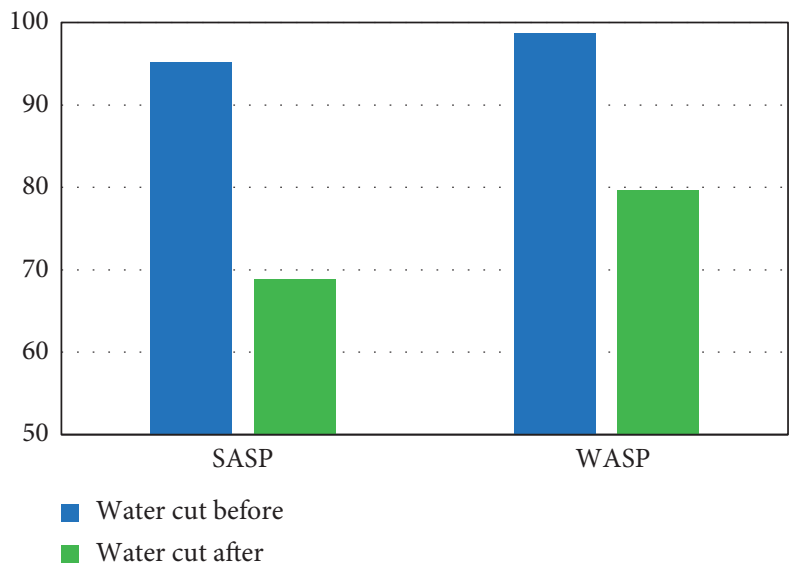

FIGURE 13: Water cut comparison.
Emulsification contributes to EOR $[24,82]$ and contribution of emulsification to IORF is even as high as 30\% [35]. SASP in B-1-D took effect earlier than WASP. This is probably caused by fast interaction of $\mathrm{NaOH}$ with oil as well as rock which leads to emulsification. Emulsification mechanism in ASP flooding as well as chemical flooding is the very mechanism to be further investigated.

\section{Injection-Production Ability}

Injection capacity and liquid production capacity reflect reservoir energy supplement ease. Generally, the injectivity index is used to characterize water absorption capacity and injectivity. However, since it is time-consuming and laborintensive to get water injectivity index, the apparent water injectivity index is commonly used in China [93, 101]. Compared with the water absorption index, the apparent water absorption index test is relatively simple. Figure 13 compared apparent water injectivity index drop in two blocks. The maximum apparent injectivity index drop in B-2-X and B-1-D was $23.1 \%$ and $59.0 \%$, respectively. The decrease of the apparent injectivity index in B-2-X was lower than that of B-1-D, indicating that the weak alkali system injectivity was better than the strong alkali one. Figures 14 and 15 [40] shows the liquid production index drop in two blocks. Compared with water flooding, the SASP and WASP production fluid indexes decreased by $31.3 \%$ and $54.5 \%$, respectively, indicating $\mathrm{B}-2-\mathrm{X}$ production loss is much less than that in B-1-D. However, compared with other strong ASP field test areas where fluid production index decreased by $68 \%-85 \%$ [41], B-1-D had the smallest decrease in production fluid index. Due to the high $\mathrm{CO}_{2}$ content in formation, some $\mathrm{NaOH}$ were converted to $\mathrm{Na}_{2} \mathrm{CO}_{3}$, which explains why after the injection of alkali into B-1-D, no hydroxide ion (OH-) was detected in the produced liquid 


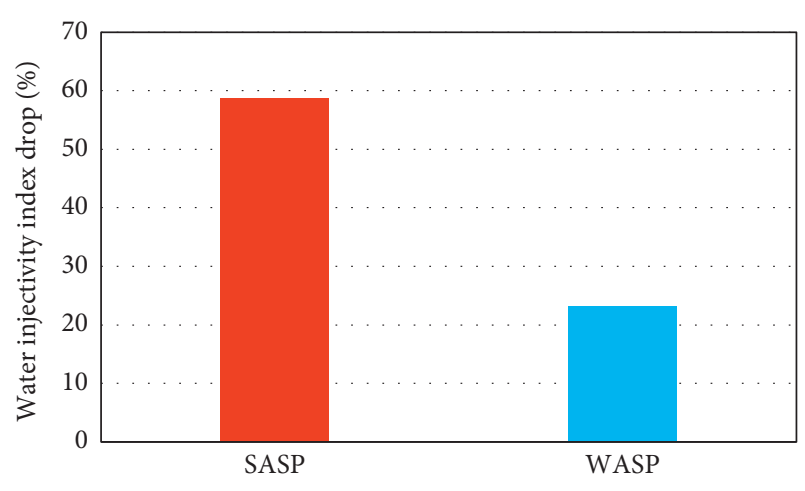

Figure 14: Water injectivity index drop.

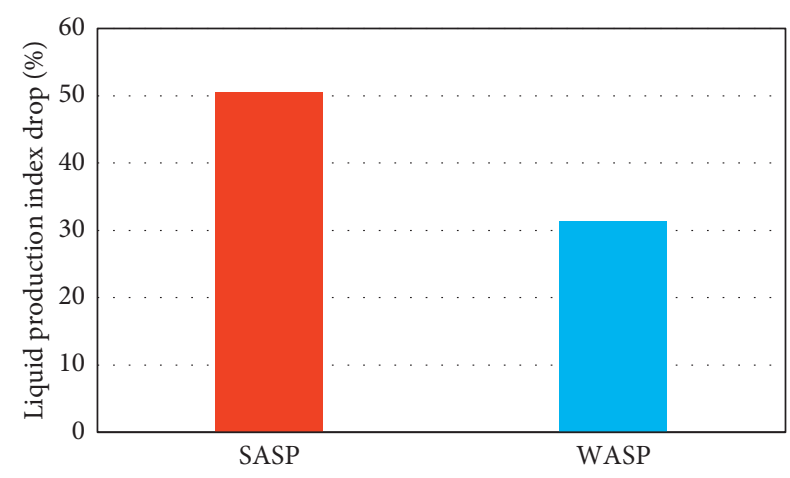

FIgURE 15: Fluid production index drop.

[80]. After ASP injection, the injection capacity and fluid production capacity decrease, which is mainly related to the polymer's adsorption and retention in porous media. This is similar to polymer flooding. The polymer's resistance factor (RF) and residual resistance factor (RRF) are comprehensive reflections of polymer retention in the formation, although recent studies have shown that it is not easy to accurately test their values [105-107]. The added alkali acts as a salt to compare the molecular chain of the polymer in the ASP, making the polymer molecular chain smaller and easier to enter smaller pores. Therefore, the injection capacity of the ASP flooding is better than the same well spacing and viscosity polymer flooding, as shown from a comparative survey of injection capacity and fluid production capacity of polymer flooding and strong ASP flooding in Daqing Oilfield [93]. Reference [41] reported comparison of weak ASP flooding and polymer flooding injection capacity and liquid production capacity. The SASP injection and production capacity is inferior to WASP, probably due to the stronger emulsifying ability of strong alkali $\mathrm{NaOH}$ and very serious formation damage ability. Under the same conditions, $\mathrm{NaOH}$ has much stronger emulsifying ability than $\mathrm{Na}_{2} \mathrm{CO}_{3}$, which has been confirmed by many laboratory experiments $[56,97]$. Laboratory study [108] showed that the injection ability became worse after the emulsion was formed, and the drop in production capacity of the emulsion (ASP + oil) injection was greater than the ASP injection. Field tests in Daqing Oilfield have confirmed that emulsification is also closely related to residual oil saturation and water content
[72]; especially when formations have high remaining oil saturation, it is easy to form 30 times high viscosity water-inoil (W/O) emulsions [80]. Compared with $\mathrm{Na}_{2} \mathrm{CO}_{3}$, the more severe harmful effects of $\mathrm{NaOH}$ on the formation have been confirmed by many early scholars [109-111]. High pH $\mathrm{NaOH}$ is more likely to cause more formation mineral dissolution and lower permeability than $\mathrm{Na}_{2} \mathrm{CO}_{3}$, especially in anhydrite-rich formations.

\section{Oil Production Rate}

Figure 16 [40] shows the oil production rates in two blocks. Oil production rate is defined as the ratio of annual oil production to recoverable geological reserves. Figure 16 shows that in the initial stage when ASP takes effect, the production rate of WASP is lower than that of SASP. The obvious taking effect time in SASP and WASP is $0.049 \mathrm{PV}$ and $0.1246 \mathrm{PV}$, respectively, indicating fast positive response time of SASP. In the peak production period, the production rate of WASP is obviously higher than that of SASP. The maximum production rates of WASP and SASP are $11.81 \%$ and $9.49 \%$, respectively. The other two ASP flooding field tests (X-2-Z and $\mathrm{B}-3-\mathrm{X})$ with the same well spacing proved that $\mathrm{B}-1-\mathrm{D}$ and $\mathrm{B}-2-\mathrm{X}$ had good performance [38]. The average oil production rates of the $\mathrm{X}-2-\mathrm{Z}$ strong alkali and B-3-X weak alkali field tests are 3.19\% and 5.95\% [41], indicating the weak alkali system production rate is obviously higher than the strong alkali system. The oil increase factor is the ratio of daily oil production after the effect and before the effect [101]. For typical polymer flooding in Daqing, the oil increase factor is 2.42 to 3.07 [101]. The maximum oil increase factor of WASP and SASP was 9.93 and 3.70, respectively [80]. Because the formation thickness and geological reserves of the two test areas are different, it is difficult to directly compare the absolute oil increase. However, in the practice of field tests, the monthly oil increase per thickness formation is often used. A factor of monthly oil increase per thickness (MOIPT) which is defined as the monthly oil increase divided by the effective reservoir thickness during the peak production stage is often used in field tests in China. TMOIPT of the WASP and SASP is $41.01 \mathrm{t} / \mathrm{m}$ and $29.35 \mathrm{t} / \mathrm{m}$, and the WASP is 1.40 times the strong one [80]. It can be seen that oil production parameters of WASP are better than those of SASP during the peak oil production period.

\section{Scaling}

Statistics $[95,112]$ on multiple field tests in Daqing Oilfield show that scaling occurred when the chemical agent broke through or at end of main ASP slug. Scaling time of SASP is earlier than WASP. The first scaling in production wells in B-1-D and B-2-X happened at 0.162 PV and 0.389 PV [80]. The proportion of scaling wells in B-2-D is significantly higher than that in $\mathrm{B}-2-\mathrm{X}$. The production wells' scaling ratio in B-1-D and B-2-X is $79.4 \%$ and $47.7 \%$, respectively, as shown in Figure 17. Production well scaling ratio reached $98 \%$ in central producers in B-1-D, while the ratio for B-2-X central producers was $55.65 \%$ [80]. As mentioned earlier, the 


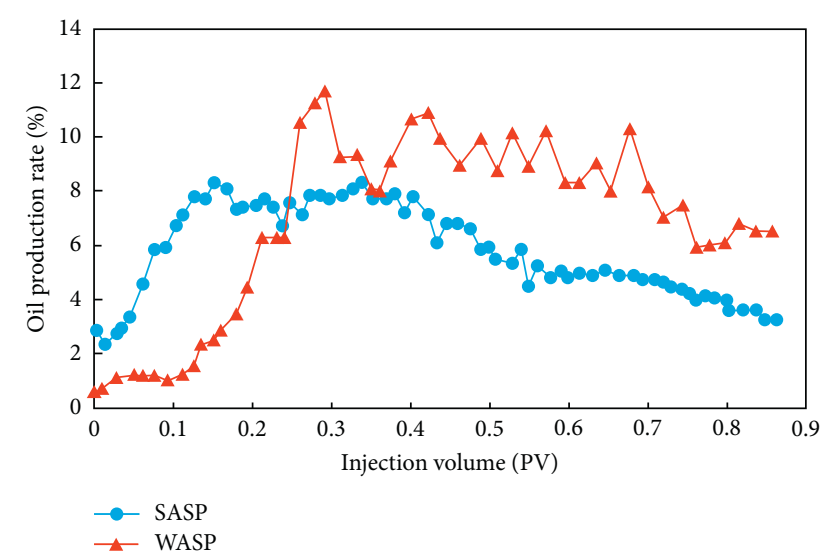

FIgURE 16: Oil production rate [40].

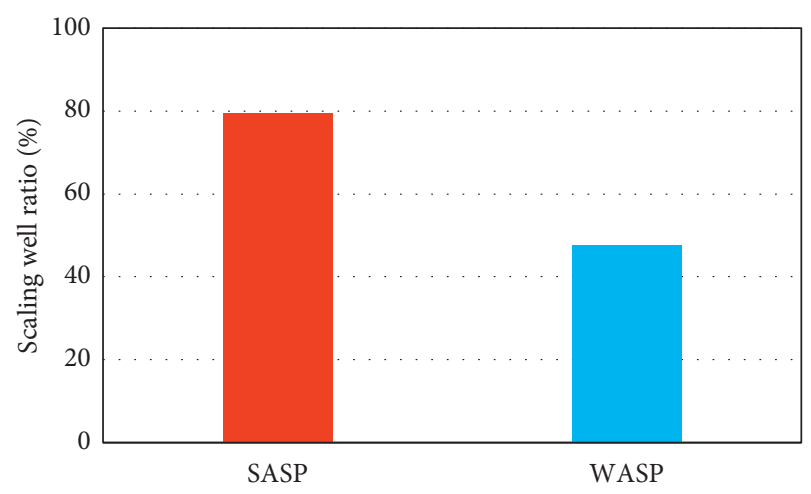

FIGURE 17: Scaling well ratio comparison.

high $\mathrm{CO}_{2}$ content in the strong alkali test area (B-1-D) makes the injected strong alkali change to weak alkali, which reduces the degree of scaling to a certain extent. This is well reflected in the fact that the type of scale and the proportion of scaling wells in B-1-D are lower than other strong ASP flooding field tests. The scaling ratio of production wells in the N-5 ASP flooding in Daqing is significantly higher than that in B-1-D. The type of scale in B-2-X is always carbonate scale, and the proportion of silica scale is very low. Generally, in the early stage of strong ASP flooding, loose carbonate scale formed. In the later stage of scaling, mixed scale of carbonate scale and silica scale formed. In the later stage of scaling, a dense and hard silica scale is found [113, 114]. However, unlike other strong ASP tests characterized by early scale type of calcium carbonate scale and the middle and late stages of silica scale, B-1-D is mainly dominated by carbonate scale from the early stage to the late stage $[72,75,80,81]$. Carbonate scale is always higher than silica scale. The content of calcium carbonate and silica scale is $76.9 \%$ and $3.48 \%$ during the initial stage of scale formation. Mixed scale formed in the middle scaling stage, with carbonate scale reducing to $49.42 \%$ and silica scale increasing to $18.08 \%$. Mixed scale is found in the later scaling stage, and carbonate scale decreased to $41.29 \%$ and the silica scale increased to $35.11 \%$ [80]. However, in other strong ASP test blocks, the proportion of silica scale in the late stage of N-5 and $\mathrm{B}-1-\mathrm{X}$ was as high as $60 \%$ and $67.7 \%$, respectively.
Another 120-meter strong ASP test L-B-D scale behaved quite different from B-1-D [95]. In the initial scaling stage, carbonate scale ratio was $70 \%$ and silicon scaling was around $10 \%$. In the middle stage of scaling, the content of carbonate and silicate scale is about $40 \%$ and $50 \%$. In scaling peak stage, the content of carbonate scale is about $10 \%$, while the content of silicate scale is about $70 \%$. According to the field test experience of Daqing Oilfield, the smaller the well spacing, the lighter the scaling. Thus, scaling in B-1-D is much severe than B-2-X but less severe than other strong ASP flooding field tests. It is worth to note that smaller well spacing helps to reduce scaling content $[115,116]$.

\section{Chromatographic Separation}

During the ASP migration process, due to effects of competitive adsorption, ion exchange, and retention loss, the chromatographic separation of polymers, alkalis, and surfactants will occur. Chromatographic separation is regarded to have negative effect on oil recovery. The time of each component to reach the production wells is different. The relative output ratio to injected chemical concentration is also different [95]. Laboratory tests have shown that the adsorption loss of the surfactant is the largest, the polymer is the smallest, and the alkali is between them. The breakthrough order of the three chemical agents is polymer first, alkali second, and surfactant last [117]. The order in which the components appear in the field test is basically the same as the order in which the components appear in the laboratory. Although the chromatographic separation in the field test is not as severe as in the laboratory [117], the field test also confirmed that the adsorption of surfactants is related to the clay content. Compared with the strong base ternary complex flooding, the weak base ternary complex flooding has a weaker chromatographic separation [41], which shows that the polymer-alkali interval and the alkali-surfactant interval are smaller. In addition, the chemical agent breakthrough time interval in these two test areas is smaller than that in other early strong alkali field tests [113]. Studies $[95,118]$ also show that the relative recovery of chemical agents (polymer 0.67, surfactant 0.058) during the peak period of the B-1-D ASP flooding is higher than that of the other three strong alkali test zones (L-B-D, N-5, and X-2) and may be related to the higher content of $\mathrm{CO}_{2}$ in this test block. It should be noted that $\mathrm{OH}^{-}$was not detected in the production liquid of B-1-D. The chromatographic separation of the ASP flooding is very complicated. It not only involves the interaction between various components but also the interaction between various components and clay minerals, which requires in-depth research.

\section{Economic Performance}

The economic issues of ASP flooding have always attracted much attention. One important reason is that ASP compound flooding significantly increases costs compared to polymer flooding. Therefore, it is not appropriate to evaluate the ASP flooding solely from the oil production increase or IORF, especially in a low oil price era, and thus the 
TABle 20: Economical benefit comparison.

\begin{tabular}{lccc}
\hline Block & Input-output ratio & ROI & FIRR \\
\hline SASP & $1: 2.3$ & 12.9 & 18.0 \\
WASP & $1: 3.7$ & 19.1 & 22.3 \\
\hline
\end{tabular}

relationship between cost and benefit is more important. The three factors that determine ASP flooding economic benefits are cost, crude oil price, and incremental oil production which is related to IORF, but the only controllable factors are cost and incremental oil production. Several successful cases completed in Daqing show that the cost of ASP flooding can be controlled at US 24-35\$/bbl [35]. Even under low oil price conditions, ASP flooding can be profitable. Generally speaking, before the field tests, the economic benefit evaluation is carried out based on the numerical simulation predicted oil recovery factor and oil production. The commonly used indicators in the economic benefit evaluation are the input-output ratio (IR), return on investment (ROF), and financial internal rates of return (FIRR) after tax. Because the accuracy of numerical simulation is affected by a variety of factors, especially uncontrollable risks, coupled with the operator's technical and management level limitations, the prior economic benefit evaluation is only applicable to the case to case study. Based on the actual crude oil sales price and the field test input, the economic benefit indicators of the two tests are compared in Table 20 [20]. The FIRR of SASP and WASP is $18.0 \%$ and $22.3 \%$, which are much higher than the local oil industry's benchmark value of $12 \%$. The economic benefit evaluation reflected that the economic benefit indicators of WASP in B-2-X are better than that of B-1-D, although the incremental oil production in the SASP is more than that of WASP. The cost analysis of the two tests shows that the comprehensive cost of WASP in $\mathrm{B}-2-\mathrm{X}$ is lower than that of SASP in B-1-D. More cost comparison is given in reference [119]. It is worth mentioning that even oil price was low in the past three years, latest information indicated that ASP flooding in Daqing is higher than 4 million tons [84].

\section{Conclusions}

(1) From geological and petrophysical comparison of SASP in B-1-D and WASP in B-2-X, it is believed that reservoir conditions in B-1-D are better than $\mathrm{B}-2-\mathrm{X}$, which is characterized by higher permeability, larger formation thickness, and better deposition condition. There are more layers in B-1-D than $\mathrm{B}-2-\mathrm{X}$, which is less beneficial to water flooding but may be more suitable to employ ASP flooding. Some uncertainties exist regarding geology. Both ASP flooding tests are conducted in SCL which is defined different from both geology and development aspects.

(2) Parameters of reservoir temperature, oil viscosity, and formation brine salinity in B-1-D and B-2-X are so similar that they can be regarded as the same from EOR perspective. Asphaltene and resin content in B-2-X block is a bit higher than that in B-1-
D. The average formation permeability of $\mathrm{B}-2-\mathrm{X}$ is lower than $\mathrm{B}-1-\mathrm{D}$, and this is evidenced by high clay content which is more likely to lead to chemical adsorption.

(3) Both ASP flooding field tests have the same well pattern and well spacing. Central well area has the same well configuration. Chemical injection schemes in these two blocks are quite similar. Polymer concentration of SASP is slightly higher than that in WASP but with smaller polymer molecular weight in some chemical flooding stages. Both injected ASP can meet the ultralow oil-water IFT requirement. Ultralow IFT region of SASP is larger than that of WASP. The surfactant HABS used in SASP is a bit more mature than the surfactant DPS used in WASP. Polymer control degree in B-2-X is slightly higher than that in B-1-D.

(4) These two large-scale ASP flooding field tests in Daqing indicated that ASP flooding can get a IORF of $30 \%$ OOIP. Considering the global reservoirs' average recovery is 33\% OOIP, this is great achievement. The IORF in these two blocks is higher (10\% OOIP) than other ASP flooding tests in Daqing. These two tests conducted in similar reservoir conditions convinced that WASP can have the same and even higher IORF than SASP, which is different from previous conclusion. Since the reservoir condition (geology, permeability, and remaining oil saturation) of SASP is better than WASP, the IORF in B-1-D should have been higher than that in B-2-X. In addition, this strong ASP flooding has displayed some characteristics of weak ASP flooding, which partly accounts for its higher IORF than other strong ASP flooding tests.

(5) Before chemical slugs are injected, comprehensive water cut in central well area in B-1-D and B-2-D was $95.2 \%$ and $98.7 \%$, respectively. This $3 \%$ water cut difference is very large from EOR perspective. Compared with WASP, water cut drop in SASP is larger and responding time is earlier, which may be caused by faster interaction of strong alkali over weak alkali with formation rock and fluids. Although SASP has three months longer low water cut duration than WASP, this may be attributed to its lower initial water cut before chemical flooding and much more fracturing measures. Better water cut performance in B-1-D than B-2-X does not show its superiority except for emulsification.

(6) Injection pressure increase degree in $\mathrm{B}-2-\mathrm{X}$ is smaller than B-1-D, indicating better injectivity and fluid production ability of WASP over SASP. The injection pressure performance difference is caused by scaling resulted from alkali, which reduced formation permeability. Both laboratory studies and field coring analysis proved the permeability loss due to alkali injection. Although scaling well 
ratio in $\mathrm{B}-1-\mathrm{D}$ is much higher than that in $\mathrm{B}-2-\mathrm{X}$, the scaling is much less severe than other strong ASP tests. Compared with WASP test, more fracturing measures were taken in SASP test.

(7) It is observed that production wells have positive effects earlier in B-1-D than in B-2-X and larger emulsification capacity. The stronger emulsification ability of $\mathrm{NaOH}$ over $\mathrm{Na}_{2} \mathrm{CO}_{3}$ partly resulted in larger fluid production capacity loss. Strong emulsification may harm injectivity and productivity. The higher remaining oil saturation in B-1-D makes emulsification more easy to happen. Although emulsification is believed to contribute to IORF, it also has negative effect on fluid production capacity. Further investigation is needed on emulsification mechanisms in ASP flooding.

(8) The scaling ratio and extent in production wells in B-1-D are much higher than that in B-2-X. The scaling increased the development cost. Due to high $\mathrm{CO}_{2}$ content in formation in $\mathrm{B}-1-\mathrm{D}$, some $\mathrm{NaOH}$ are transformed into $\mathrm{Na}_{2} \mathrm{CO}_{3}$, which helped to reduced scaling degree. The scaling in B-1-D is quite different from other strong ASP flooding field tests and showed some characteristics of weak ASP flooding. This makes it possible to used $\mathrm{NaOH}$ as alkali for ASP flooding in $\mathrm{CO}_{2}-$ rich reservoirs. IORF of SASP in B-1-D is much higher than all the other strong ASP flooding field tests in Daqing, which is partly due to discounted scaling effect.

(9) Both of these two tests are very successful from technical and economic aspects. The incremental oil recovery in these two blocks are the same, and SASP in $\mathrm{B}-1-\mathrm{D}$ produced more oil due to larger reserves, however, input-output ratio, ROI, FIRR of SASP are all lower than WASP. Thus, it is prudential to get a conclusion that WASP is better than SASP. The success of these two tests may help to develop ASP flooding.

(10) Alkali plays a vital important role in ASP flooding. Although some differences (oil layers number, surfactant type and performance, polymer control degree, and reservoir management level) may lead to some uncertainties, taking geological condition, injection scheme, chemicals, recovery performance, economic parameters, and other field test results into account, it is believed that it is the alkali difference that most causes the performance difference and WASP is better than SASP under Daqing reservoir condition.

(11) ASP flooding is the most attractive chemical flooding which has been tested in many oilfields. After huge effort, ASP flooding was put into commercial application in Daqing Oilfield. From 2016 to 2018, annual ASP flooding oil production in Daqing exceeded 4 million tons and had share higher than $10.28 \%$.

\section{Nomenclature}

EOR: Enhanced oil recovery

ASP: Alkali-surfactant-polymer

WASP: Weak alkali-surfactant-polymer

SASP: Strong alkali-surfactant-polymer

IORF: Incremental oil recovery factor

IR: Input-output ratio

OOIP: Original oil in place

FCL: First-class layer

SCL: Second-class layer

TCL: Third-class layer

IFT: Interfacial tension

ROI: Return on investment

ROF: Return on investment

FIRR: Financial internal rates of return

HABS: Heavy-oil alkybenzoyl sulfonate

DPS: Daqing petroleum sulfonate

TDS: Total dissolved solids

TAN: Total acid number

RW: $\quad$ Reference water flooding

RF: $\quad$ Resistance factor

RRF: Residual resistance factor

MOIPT: Monthly oil increase per thickness.

\section{Data Availability}

The data used to support the findings of this study are included within the article.

\section{Conflicts of Interest}

The authors declare no conflicts of interest.

\section{Authors' Contributions}

Chen Sun and Hu Guo contributed equally to this work.

\section{Acknowledgments}

The authors wish to express their appreciation for the funding provided by the National Science and Technology Major Project of China (nos. 2016ZX05025-001-005 and 2016ZX05025-003-010), Natural Science Foundation (51834005), Yan'an University Start-Up Fund (YDBK201852), China Scholarship Council (201806440187), and Deutscher Akademischer Austauschdienst (91737128).

\section{References}

[1] G. Georgiou, S.-C. Lin, and M. M. Sharma, "Surface-active compounds from microorganisms," Nature Biotechnology, vol. 10, no. 1, pp. 60-65, 1992.

[2] S. K. Nandwani, M. Chakraborty, and S. Gupta, "Adsorption of surface active ionic liquids on different rock types under high salinity conditions," Scientific Reports, vol. 9, no. 1, pp. 1-16, 2019.

[3] S. De, S. Malik, A. Ghosh, R. Saha, and B. Saha, "A review on natural surfactants," RSC Advances, vol. 5, no. 81, pp. 65757-65767, 2015. 
[4] M. H. Mondal, S. Malik, A. Roy, R. Saha, and B. Saha, "Modernization of surfactant chemistry in the age of gemini and bio-surfactants: a review," RSC Advances, vol. 5, no. 112, pp. 92707-92718, 2015.

[5] M. H. Mondal, S. Malik, S. De, S. S. Bhattacharyya, and B. Saha, "Employment and resurrection of surfactants in bipyridine promoted oxidation of butanal using bivalent copper at NTP," Research on Chemical Intermediates, vol. 43, no. 3, pp. 1651-1670, 2017.

[6] K. Mukherjee, R. Saha, A. Ghosh, S. K. Ghosh, and B. Saha, "Efficient combination of promoter and catalyst for chromic acid oxidation of propan-2-ol to acetone in aqueous acid media at room temperature," Spectrochimica Acta Part A: Molecular and Biomolecular Spectroscopy, vol. 101, pp. 294-305, 2013.

[7] A. K. Das, A. Roy, and B. Saha, "Kinetics and mechanism of the picolinic acid catalysed chromium(VI) oxidation of ethane-1,2-diol in the presence and absence of surfactants," Transit Met Chem, vol. 26, pp. 630-637, 2001.

[8] R. Nandi, S. Laskar, and B. Saha, "Surfactant-promoted enhancement in bioremediation of hexavalent chromium to trivalent chromium by naturally occurring wall algae," Research on Chemical Intermediates, vol. 43, no. 3, pp. 16191634, 2017.

[9] K. Mukherjee, R. Saha, A. Ghosh, S. K. Ghosh, P. K. Maji, and B. Saha, "Surfactant-assisted bioremediation of hexavalent chromium by use of an aqueous extract of sugarcane bagasse," Research on Chemical Intermediates, vol. 40, no. 4, pp. 1727-1734, 2014.

[10] C. De, R. Saha, S. K. Ghosh et al., "A review of biphasic hydroformylation for long chain substrates," Research on Chemical Intermediates, vol. 39, no. 8, pp. 3463-3474, 2013.

[11] W. R. Finnerty and M. E. Singer, "Microbial enhancement of oil recovery," Nature Biotechnology, vol. 1, no. 1, pp. 47-54, 1983.

[12] Z. Wu, X. a. Yue, T. Cheng, J. Yu, and H. Yang, "Effect of viscosity and interfacial tension of surfactant-polymer flooding on oil recovery in high-temperature and high-salinity reservoirs," Journal of Petroleum Exploration and Production Technology, vol. 4, no. 1, pp. 9-16, 2014.

[13] Z. Ma, F. Ge, Q. Wang, and X. Li, "The behavior of interfacial film thinning in oil-in-water emulsion from the produced water from ASP flooding," Separation Science and Technology, vol. 55, no. 1, pp. 155-164, 2020.

[14] W. Yun, S. Chang, D. A. Cogswell et al., "Toward reservoiron-a-chip: rapid performance evaluation of enhanced oil recovery surfactants for carbonate reservoirs using a calcitecoated micromodel," Scientific Reports, vol. 10, no. 1, pp. 1-12, 2020.

[15] K. Xie, X. Lu, Q. Li, W. Jiang, and Q. Yu, "Analysis of reservoir applicability of hydrophobically associating polymer," SPE Journal, vol. 21, no. 1, pp. 001-009, 2016.

[16] K. Xie, B. Cao, X. Lu et al., "Matching between the diameter of the aggregates of hydrophobically associating polymers and reservoir pore-throat size during polymer flooding in an offshore oilfield," Journal of Petroleum Science and Engineering, vol. 177, pp. 558-569, 2019.

[17] J. Li, L. Niu, and X. Lu, "Performance of ASP compound systems and effects on flooding efficiency," Journal of Petroleum Science and Engineering, vol. 178, pp. 1178-1193, 2019.

[18] X. Han, I. Kurnia, Z. Chen, J. Yu, and G. Zhang, "Effect of oil reactivity on salinity profile design during alkaline- surfactant-polymer flooding," Fuel, vol. 254, pp. 115738-115739, 2019.

[19] X. Sui, Z. Chen, I. Kurnia, X. Han, J. Yu, and G. Zhang, "Alkaline-surfactant-polymer flooding of active oil under reservoir conditions," Fuel, vol. 262, p. 116647, 2020.

[20] R. Farajzadeh, B. L. Wassing, and L. W. Lake, "Insights into design of mobility control for chemical enhanced oil recovery," Energy Reports, vol. 5, pp. 570-578, 2019.

[21] L. Sun, X. Wu, W. Zhou, X. Li, and P. Han, "Technologies of enhancing oil recovery by chemical flooding in Daqing Oilfield, NE China," Petroleum Exploration and Development, vol. 45, pp. 636-645, 2018.

[22] S. Yuan and Q. Wang, "New progress and prospect of oilfields development technologies in China," Petroleum Exploration and Development, vol. 45, pp. 657-668, 2018.

[23] A. A. Olajire, "Review of ASP EOR (alkaline surfactant polymer enhanced oil recovery) technology in the petroleum industry: prospects and challenges," Energy, vol. 77, pp. 963-982, 2014.

[24] J. J. Sheng, "A comprehensive review of alkaline-surfactant-polymer (ASP) flooding," Asia-Pacific Journal of Chemical Engineering, vol. 9, pp. 471-489, 2014.

[25] Z. Wang, R. Pang, X. Le, Z. Peng, Z. Hu, and X. Wang, "Survey on injection-production status and optimized surface process of ASP flooding in industrial pilot area," Journal of Petroleum Science and Engineering, vol. 111, pp. 178-183, 2013.

[26] Y. Zhu, Q. Hou, G. Jian, D. Ma, and Z. Wang, "Current development and application of chemical combination flooding technique," Petroleum Exploration and Development, vol. 40, no. 1, pp. 96-103, 2013.

[27] Z. Qu, Y. Zhang, X. Zhang, and J. Dai, "A successful ASP flooding pilot in gudong oil field," in Proceedings of the SPE/ DOE Improved Oil Recovery Symposium, pp. 107-119, Tulsa, OK, USA, April 1998.

[28] W. Song, C. Yang, Z. Qu, and B. Wen, "Alkaline-surfactantpolymer combination flooding for improving recovery," in Proceedings of the International Meeting on Petroleum Engineering, pp. 1-7, Beijing, China, November 1995.

[29] Y. Zhu, X. Liu, and J. Fan, "Developments of ASP/SP flooding formulations for Huabei fault block reservoir," in Proceedings of the SPE/IATMI Asia Pacific Oil \& Gas Conference and Exhibition, pp. 1-9, Nusa Dua, Bali, Indonesia, October 2015.

[30] Q. Qi, G. Hongjun, L. Dongwen, and D. Ling, "The pilot test of ASP combination flooding in Karamay oil field," in Proceedings of the International Oil and Gas Conference and Exhibition in China, Beijing, China, November 2000.

[31] K. Panthi, H. Sharma, and K. K. Mohanty, "ASP flood of a viscous oil in a carbonate rock," Fuel, vol. 164, pp. 18-27, 2016.

[32] S. A. Shedid, "Experimental investigation of alkaline/surfactant/polymer (ASP) flooding in low permeability heterogeneous carbonate reservoirs," in Proceedings of the SPE North Africa Technical Conference and Exhibition, Cairo, Egypt, September 2015.

[33] S. Pingping, W. Jialu, Y. Shiyi, Z. Taixian, and J. Xu, "Study of enhanced-oil-recovery mechanism of alkali/surfactant/ polymer flooding in porous media from experiments," SPE J, vol. 14, no. 2, pp. 237-244, 2009.

[34] Y. Zhu, "Current developments and remaining challenges of chemical flooding EOR techniques in China," in Proceedings of the SPE Asia Pacific Enhanced Oil Recovery Conference, pp. 1-18, Kuala Lumpur, Malaysia, August 2015. 
[35] C. Jiecheng, W. Junzheng, and H. Junqing, "Key theories and technologies for enhanced oil recovery of alkali/surfactant/ polymer flooding," Acta Ecologica Sinica, vol. 35, pp. 310318, 2014.

[36] Y. Li, B. Kong, and C. Li, "Dynamic characteristics of synergistic effect between profile control technology throughout flooding and ASP flooding," Acta Ecologica Sinica, vol. 39, pp. 697-702, 2018.

[37] L. Bo and J. Hu, Daqing Oilfield Overcomes Worldclass Difficulty Producer Scaling in ASP Flooding, China Petroleum Daily, Daqing, China, 2016.

[38] H. Guo, Y. Li, D. Kong, R. Ma, B. Li, and F. Wang, "Lessons learned from alkali/surfactant/polymer-flooding field tests in China," SPE Reservoir Evaluation \& Engineering, vol. 22, no. 01, pp. 078-099, 2019.

[39] Y. Liu and L. W. Yu, "Reducing pump checking rate research and application for ASP flooding in Sanan oilfield," in Proceedings of the Proceeding of China Oil Gas Conference, pp. 737-744, Beijing, China, October 2018.

[40] H. Guo, Y. Li, F. Wang, and Y. Gu, "Comparison of strongalkali and weak-alkali ASP-flooding field tests in daqing oil field," SPE Production \& Operations, vol. 33, no. 2, pp. 353-362, 2018.

[41] H. Guo, S. Hu, H. Yan et al., "Emulsification mechanisms in alkali-surfactant-polymer (ASP) flooding enhanced oil recovery," in Proceedings of the IOR 2019-20th European Symposium on Improved Oil Recovery, Tulsa, OK, USA, April 2019.

[42] R.-S. Feng, X.-M. Zhang, J. Hu, H.-B. Li, and H. B. Li, "Alkali/surfactant/polymer flooding in the daqing oilfield class II reservoirs using associating polymer," Journal of Chemistry, vol. 2013, Article ID 275943, 6 pages, 2013.

[43] N. Lai, X. Qin, Z. Ye, Q. Peng, Y. Zhang, and Z. Ming, "Synthesis and evaluation of a water-soluble hyperbranched polymer as enhanced oil recovery chemical," Journal of Chemistry, vol. 2013, Article ID 824785, 11 pages, 2013.

[44] D. Zhu, J. Zhang, Y. Han, H. Wang, and Y. Feng, "Laboratory study on the potential EOR use of HPAM/VES hybrid in high-temperature and high-salinity oil reservoirs," Journal of Chemistry, vol. 2013, Article ID 927519, 8 pages, 2013.

[45] Y. Du, G. Zhang, J. Ge, G. Li, and A. Feng, "Influence of oil viscosity on alkaline flooding for enhanced heavy oil recovery," Journal of Chemistry, vol. 2013, Article ID 938237 , 8 pages, 2013.

[46] J. Li, W. Liu, G. Liao, L. Sun, S. Cong, and R. Jia, "Chemical migration and emulsification of surfactant-polymer flooding," Journal of Chemistry, vol. 2019, Article ID 3187075, 8 pages, 2019.

[47] D. Yin, D. Zhao, J. Gao, and J. Gai, "Experimental study of enhancing oil recovery with weak base alkaline/surfactant/ polymer," International Journal of Polymer Science, vol. 2017, Article ID 4652181, 7 pages, 2017.

[48] B. Huang, T. Dai, H. Liu, C. Fu, T. Zhu, and W. Zhang, “A study on the adjustment of emulsification degree to interlayer interference in class III reservoir," International Journal of Polymer Science, vol. 2019, Article ID 6186018, 11 pages, 2019.

[49] D. W. Green and G. P. Willhite, Enhanced Oil Recovery, Society of Petroleum Engineers, Richardson, TX, USA, 2st edition, 2018.

[50] M. Delshad, C. Han, F. K. Veedu, and G. A. Pope, "A simplified model for simulations of alkaline-surfactantpolymer floods," Journal of Petroleum Science and Engineering, vol. 108, pp. 1-9, 2013.
[51] M. Kazempour, C. S. Gregersen, and V. Alvarado, "Mitigation of anhydrite dissolution in alkaline floods through injection of conditioned water," Fuel, vol. 107, pp. 330-342, 2013.

[52] M. Kazempour, E. J. Manrique, V. Alvarado, J. Zhang, and M. Lantz, "Role of active clays on alkaline-surfactant-polymer formulation performance in sandstone formations," Fuel, vol. 104, pp. 593-606, 2013.

[53] A. Kazemi Nia Korrani, K. Sepehrnoori, and M. Delshad, "A mechanistic integrated geochemical and chemical-flooding tool for alkaline/surfactant/polymer floods," SPE Journal, vol. 21, no. 1, pp. 032-054, 2016.

[54] H. Sharma, S. Dufour, G. W. P. P. Arachchilage, U. Weerasooriya, G. A. Pope, and K. Mohanty, "Alternative alkalis for ASP flooding in anhydrite containing oil reservoirs," Fuel, vol. 140, pp. 407-420, 2015.

[55] M. Kazempour, E. Sundstrom, and V. Alvarado, "Geochemical modeling and experimental evaluation of high-pH floods: impact of Water-Rock interactions in sandstone," Fuel, vol. 92, no. 1, pp. 216-230, 2012.

[56] M. Li, M. Lin, Z. Wu, and A. A. Christy, "The influence of $\mathrm{NaOH}$ on the stability of paraffinic crude oil emulsion," Fuel, vol. 84, no. 2-3, pp. 183-187, 2005.

[57] G. Jixiang, L. Mingyuan, L. Meiqin, and W. Zhaoliang, "Investigation in the reaction of daqing crude oil with alkali," Acta Ecologica Sinica, vol. 23, pp. 20-24, 2007.

[58] S. Gang, L. Zhiwei, L. Meiqin, X. Xueqin, L. Minyuan, and W. Rongjian, "Effect of Reaction of $\mathrm{Na}_{2} \mathrm{CO}_{3}$ and Daqing crude oil/water inferfacial properties and stability of emulsion," J Northeast Pet Univ, vol. 37, pp. 73-77, 2013.

[59] J. J. Sheng, "Investigation of alkaline-crude oil reaction," Petroleum, vol. 1, no. 1, pp. 31-39, 2015.

[60] L. He, F. Lin, X. Li, H. Sui, and Z. Xu, "Interfacial sciences in unconventional petroleum production: from fundamentals to applications," Chemical Society Reviews, vol. 44, no. 15, pp. 5446-5494, 2015.

[61] S. Solairaj, C. Britton, D. H. Kim, U. Weerasooriya, and G. A. Pope, "Measurement and analysis of surfactant retention," in Proceedings of the SPE Improved Oil Recovery Symposium, pp. 1-17, Tulsa, OK, USA, April 2012.

[62] G. Y. Chen, X. L. Wu, Z. Y. Yang, F. L. Yu, J. B. Hou, and $\mathrm{X}$. J. Wang, "Study of the effect of injection water quality on the interfacial tension of ASP/crude oil," Journal of Canadian Petroleum Technology, vol. 46, no. 2, 2007.

[63] S. Huang and M. Dong, "Alkaline/surfactant/polymer (ASP) flood potential in southwest saskatchewan oil reservoirs," Journal of Canadian Petroleum Technology, vol. 43, no. 12, 2004.

[64] J. Hou, Z. Liu, S. Zhang, X. a. Yue, and J. Yang, "The role of viscoelasticity of alkali/surfactant/polymer solutions in enhanced oil recovery," Journal of Petroleum Science and Engineering, vol. 47, no. 3-4, pp. 219-235, 2005.

[65] J. R. Hou, Z. C. Liu, M. Z. Dong, X. A. Yue, and J. Z. Yang, "Effect of viscosity of alkaline/surfactant/polymer (ASP) solution on enhanced oil recovery in heterogeneous reservoirs," Journal of Canadian Petroleum Technology, vol. 45, no. 11, pp. 27-33, 2006.

[66] A. Kamel and S. N. Shah, "Effects of salinity and temperature on drag reduction characteristics of polymers in straight circular pipes," Journal of Petroleum Science and Engineering, vol. 67, no. 1-2, pp. 23-33, 2009.

[67] M. H. Sedaghat, A. Hatampour, and R. Razmi, "Investigating the role of polymer type and dead end pores' distribution on 
oil recovery efficiency during ASP flooding," Egyptian Journal of Petroleum, vol. 22, no. 2, pp. 241-247, 2013.

[68] Y. Assef, D. Arab, and P. Pourafshary, "Application of nanofluid to control fines migration to improve the performance of low salinity water flooding and alkaline flooding," Journal of Petroleum Science and Engineering, vol. 124, pp. 331-340, 2014.

[69] Y. Li, W. Zhang, B. Kong et al., "Mixtures of anionic/cationic surfactants: a new approach for enhanced oil recovery in low-salinity, high-temperature sandstone reservoir," SPE Journal, vol. 21, no. 4, pp. 1164-1177, 2016.

[70] W. Fang, H. Jiang, J. Li et al., "A new experimental methodology to investigate formation damage in clay-bearing reservoirs," Journal of Petroleum Science and Engineering, vol. 143, pp. 226-234, 2016.

[71] S. Khorsandi, C. Qiao, and R. T. Johns, "Displacement efficiency for low salinity polymer flooding including wettability alteration," SPE Journal, vol. 22, no. 2, pp. 417-430, 2017.

[72] Y. E. Wang, "Second class layer characterics and ASP flooding field test in daqing oilfield sazhong district," Master thesis, Zhejiang University, Hangzhou, China, 2014.

[73] Li Yan, "Technical research on ASP flood for poor reservoirs in eastern fault of B-1 region," Master Thesis, Daqing petroleum institute, Daqing, China, 2008.

[74] Y. Fu, "A study on dynamic development regulation of weak base ASP flooding in beierxi sub-layers," Master thesis, Northeast Petroleum University, Daqing, China, 2011.

[75] J. Wang, "The research of triple compund flooding development effect evaluation in the east of the fault block in Beiyi district," Master thesis, Northeast Petroleum University, Daqing, China, 2013.

[76] Y. Yan, "Study the formulation of alkaline/surfactant/polymer flooding system for the Gaotaizi second reservoir," Master thesis, Daqing Petroleum Insitute, Daqing, China, 2006.

[77] L. Bailin, Z. Yingying, D. Sujuan, J. Yong, and L. Zhang, "Adsorption properties of asp flooding system for the central reservoir in daqing," J Northeast Pet Univ, vol. 38, 2014.

[78] H. Pu and Q. Xu, "An update and perspective on field-scale chemical floods in daqing,China," in Proceedings of the SPE Middle East Oil and Gas Show and Conference, pp. 1-8, Manama, Bahrain, March 2009.

[79] O. Abib, F. J. Moretti, C. Mei, and Y. Yang, "Application of geological modeling and reservoir simulation to the west Saertu area of the daqing oil field," SPE Reservoir Engineering, vol. 6, no. 1, pp. 99-106, 2011.

[80] C. Jiecheng, W. Junzheng, and W. Di, ASP Flooding Technlogy, China Petroleum Industry Press, Beijing, China, 1st edition, 2013.

[81] J. Cheng, ASP Flooding Technology, Petroleum Industry Press, Beijing, China, 2019.

[82] J. J. Sheng, Modern Chemical Enhanced Oil Recovery:theory and Practice, 2011.

[83] Y. Zhu and M. Lei, "Effects of crude oil components on the interfacial tension between oil and surfactant solutions 2015," in Proceedings of the SPE Asia Pacific Enhanced Oil Recovery Conference, Kuala Lumpur, Malaysia, August 2015.

[84] X. Wu, "Research progress in the surfactants for complex flooding in Daqing Oilfield," Petroleum Geology \& Oilfield Development in Daqing, vol. 38, no. 5, pp. 183-188, 2019.

[85] C. Huaqing, Daqing Oilfield EOR Theory and Practice, Petroleum Industry Press, Beijing, China, 2006.
[86] F. Huang, T. Wei, and F. Zhihui, "Physicochemical properties and characteristics of the formation water in the northern part of songliao basin," Pet Geol Oilf Dev Daqing(PGOD), vol. 16, pp. 23-25, 1997.

[87] Y. Zhu, Y. Zhang, J. Niu, W. Liu, and Q. Hou, "The research progress in the alkali-free surfactant-polymer combination flooding technique," Petroleum Exploration and Development, vol. 39, no. 3, pp. 371-376, 2012.

[88] D. Wang, P. Han, Z. Shao, W. Hou, and R. S. Seright, "Sweep-improvement options for the daqing oil field," SPE Reservoir Evaluation \& Engineering, vol. 11, no. 1, pp. 22-26, 2008.

[89] D. Wang, C. Jiecheng, W. Junzheng, Y. Zhenyu, and Y. Yuming, "Summary of ASP pilots in Daqing oil field," in Proceedings of the SPE Asia Pacific Improved Oil Recovery Conference, Kuala Lumpur, Malaysia, October 1999.

[90] D. Wang, C. Jiecheng, L. Qun, L. Lizhong, Z. Changjiu, and H. Jichun, "An Alkaline bio-surfactant polymer flooding pilots in daqing oil field," in Proceedings of the SPE Asia Pacific Improved Oil Recovery Conference, p. 12, Kuala Lumpur, Malaysia, October 1999.

[91] D. Wang, C. Jiecheng, W. Junzheng, W. Fenglan, I. Huabin, and G. Xiaohong, "An alkaline/surfactant/polymer field test in a reservoir with a long-term $100 \%$ water cut," in Proceedings of the SPE Annual Technical Conference and Exhibition, New Orleans, LA, USA, September 1998.

[92] W. Demin, Z. Zhenhua, C. Jiecheng, Y. Jingchun, G. Shutang, and L. Li, "Pilot test of alkaline surfactant polymer flooding in daqing oil field," SPE Reservoir Engineering, vol. 12, no. 4, pp. 229-233, 1997.

[93] G. Shutang, L. Huabin, and L. Hongfu, "Laboratory investigation of combination of alkali/surfactant/polymer technology for Daqing EOR," SPE Reservoir Engineering, vol. 10, no. 3, pp. 194-197, 1995.

[94] F. Zhao, Y. Ma, J. Hou, J. Tang, and D. Xie, "Feasibility and mechanism of compound flooding of high-temperature reservoirs using organic alkali," Journal of Petroleum Science and Engineering, vol. 135, pp. 88-100, 2015.

[95] L. Jie, C. Jinfeng, and H. Mengqu, "Production performance characteristics of the strong alkali ASP flooding," Pet Geol Oilf Dev Daqing (PGOD), vol. 34, pp. 92-97, 2015.

[96] S. Rue, Z. Dong, X. Cong et al., "An evaluation on strong base ASP flooding efficiency of multiple layers the oil layer developed degree after ASP flooding," in Proceedings of the SPE Asia Pacific Enhanced Oil Recovery Conference, Kuala Lumpur, Malaysia, August 2015.

[97] C. S. Gregersen, M. Kazempour, and V. Alvarado, "ASP design for the Minnelusa formation under low-salinity conditions: impacts of anhydrite on ASP performance," Fuel, vol. 105, pp. 368-382, 2013.

[98] C. Jinfeng, L. Jie, and L. Zhang, "Injection opportunity of ASP flooding in daqing oilfield," Pet Geol Oilf Dev Daqing(PGOD), vol. 34, pp. 91-96, 2015.

[99] L. Xiuping, "Exploration characteristics and influencing factors of weak base ASP flooding," Unconventional Oil and Gas, vol. 1, pp. 37-42, 2014.

[100] R. Reichenbach-Klinke, A. Stavland, D. Strand, B. Langlotz, and G. Brodt, "Can associative polymers reduce the residual oil saturation?" in Proceedings of the SPE EOR Conference at Oil and Gas West Asia, Muscat, Oman, March 2016.

[101] W. Dongmei, D. Huanzhong, L. Changsen, F. Xiaofei, and N. Jun, "Review of practical experience of polymer flooding at daqing," SPE Reservoir Evaluation \& Engineering, vol. 12, no. 3, pp. 470-476, 2009. 
[102] C. Jiecheng, Q. Wang, J. Wang, C. Li, and W. Shi, "Ca/Si scale sedimentary modelin the strong-base ASP flooding block and scaling prediction," Acta Ecologica Sinica, vol. 37, pp. 653-659, 2016.

[103] C. Jiecheng, Z. Wan-Fu1, W. Qing-Guo, C. Tie-Xin, and Z. Guang-Dong, "Morphology and crystallization character of calcium carbonate in scaled sample formed during alkaline-surfactant-polymer(ASP) flooding in daqing oilfield," Chemical Research in Chinese Universities, vol. 33, pp. 5-9, 2012.

[104] Q. Gao, Research on Chemistry of Scaling and Descaling Process in Concentrated Alkali ASP Flooding, Northeast Petroleum Univeristy, Heilongjiang, China, 2013.

[105] R. N. Manichand and R. Seright, "Field vs. Laboratory polymer-retention values for a polymer flood in the tambaredjo field," SPE Reservoir Evaluation \& Engineering, vol. 17, no. 3, pp. 314-325, 2014.

[106] G. Zhang and R. S. Seright, "Hydrodynamic retention and rheology of EOR polymers in porous media," in Proceedings of theSPE International Symposium on Oilfield Chemistry, pp. 13-15, The Woodlands, Tx, USA, April 2015.

[107] R. S. Seright, "How much polymer should Be injected during a polymer flood? Review of previous and current practices," SPE Journal, vol. 22, no. 1, pp. 1-18, 2017.

[108] Z. Weiyao, J. Yan, and L. Yunqian, Enhanced Chemical Flooding Complex Percolation and Development Method, China Science Press, Beijing, China, 1st edition, 2013.

[109] M. Baviere, Basic Concepts in Enhanced Oil Recovery Processes, Springer, Berlin, Germany, 1991.

[110] L. Huang, P. Yang, and T. Qin, "A study of caustic consumption by clays," in Proceedings of the SPE/DOE fifth Enhanced Oil Recovery Symposium, Tulsa, OK, USA, April 1986.

[111] K. H. Cheng, "Chemical consumption during alkaline flooding: a comparative evaluation," in Proceedings of the SPE Enhanced Oil Recovery Symposium, pp. 1-14, Tulsa, OK, USA, April 1986.

[112] K. Song, X. Dong, J. He, and J. Yang, "Scaling phenomenon in base ASP flooding," Journal of Chinese Universities, vol. 27, pp. 73-78, 2014.

[113] C. Jiecheng, W. Qingguo, Z. Tianfu, L. Su, C. Tiexin, and Z. Guangdong, "Synthesis and application of silicon scale inhibitor SY-KD under the ASP flooding system," Chemical Journal of Chinese Universities, vol. 35, pp. 332-337, 2014.

[114] C. Jiecheng, Z. Wanfu, Z. Yusheng et al., "Scaling principle and scaling prediction in ASP flooding producers in daqing oilfield," in Proceedings of SPE Enhanced Oil Recovery Conference, pp. 1-6, Kuala Lumpur, Malaysia, July 2011.

[115] J. Cheng, W. Zhou, Q. Wang et al., “Technical breakthrough in production engineering ensures economic development of ASP flooding in daqing oilfield," in Proceedings of the SPE Asia Pacific Oil \& Gas Conference and Exhibition, Adelaide, Australia, October 2014.

[116] H. Guo, Y. Q. Li, Y. Shu, F. Wang, D. Kong, and R. C. Ma, "Comparison of scaling in strong alkali and weak alkali ASP flooding pilot tests," in Proceedings of the 19th European Symposium on Improved Oil Recovery, Stavanger, Norway, April 2017.

[117] D. Li, M. Shi, W. Demin, Z. Li, and H. Fei, "Chromatographic separation of chemicals in alkaline surfactant polymer flooding in reservoir rocks in the daqing oilfield," in Proceedings of the SPE International Symposium on Oilfield Chemistry, pp. 1-11, The Woodlands, TX, USA, April 2009.
[118] Y. Wang, "The field test result of ASP flooding with weak alkalin in the secondary reservoir of northern daqing oilfield," Inn Mongulia Petrochemical Ind, vol. 135-9, 2014.

[119] H. Guo, Y. Li, R. C. Ma, F. Y. Wang, and Z. Shihu, "Evaluation of three large scale ASP flooding field tests," in Proceedings of the 19th European Symposium on Improved Oil Recovery, Stavanger, Norway, April 2017. 